\title{
THE COMPLEXITIES OF HEALTH STATUS AND ITS INFLUENCING FACTORS AMONG PEOPLE LIVING ALONG THE HUNGARIAN- ROMANIAN BORDER
}

PhD Thesis

\author{
Erika Nédó MD
}

Supervisor:

Edit Paulik MD, PhD

Department of Public Health

Faculty of Medicine, University of Szeged

Szeged, 2012 


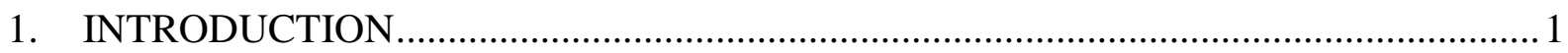

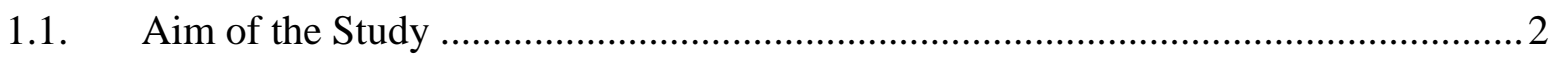

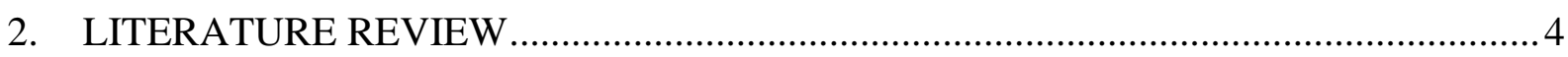

2.1. Measuring health at population level............................................................... 4

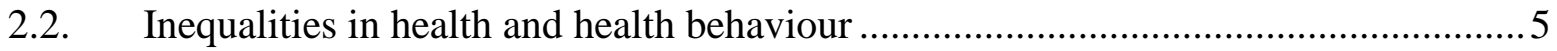

2.3. Role of prevention in enhancing health at population level ................................... 6

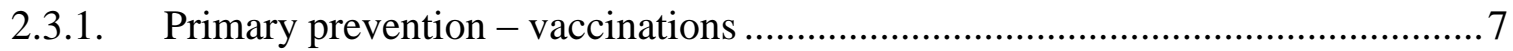

2.3.2. Secondary prevention - screening .................................................................. 8

2.4. The use of health care - patient satisfaction ......................................................... 10

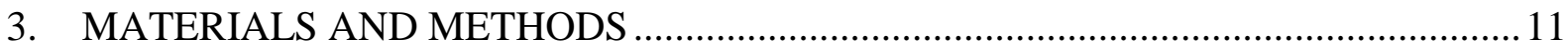

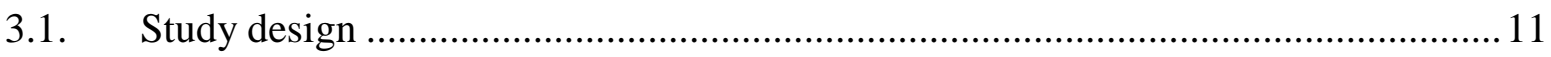

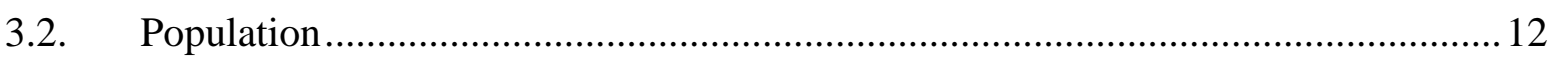

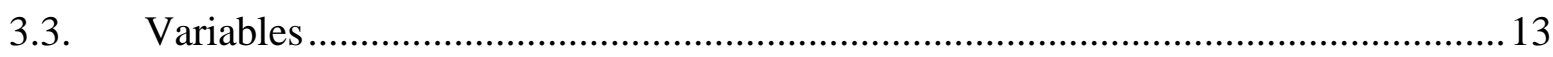

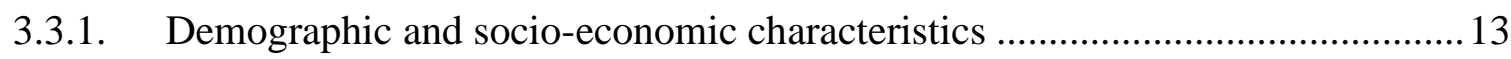

3.3.2. Health status and health behaviour characteristics ......................................... 14

3.3.3. Prevention-related characteristics ................................................................ 15

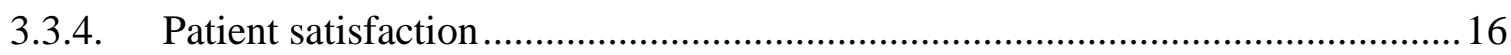

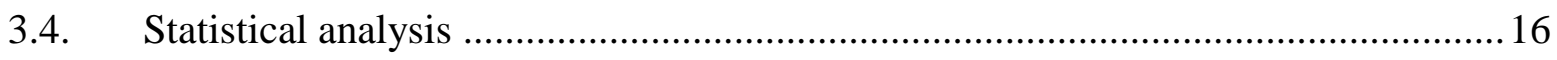

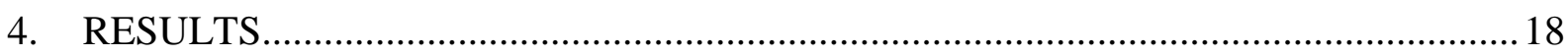

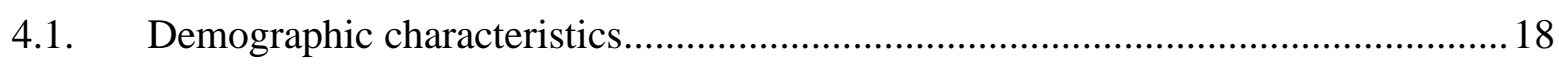

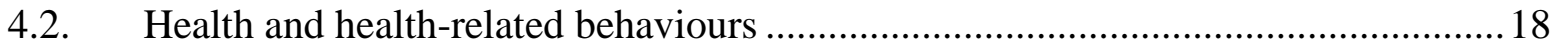

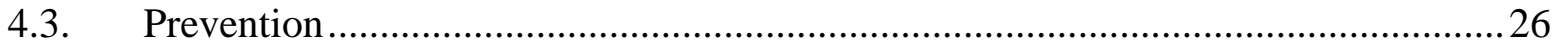

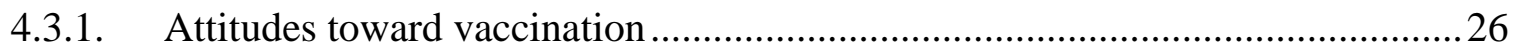

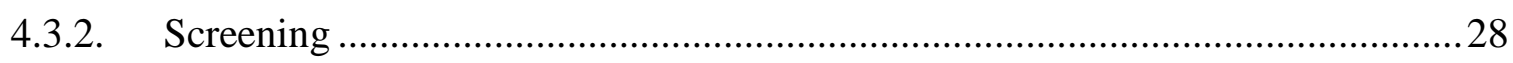

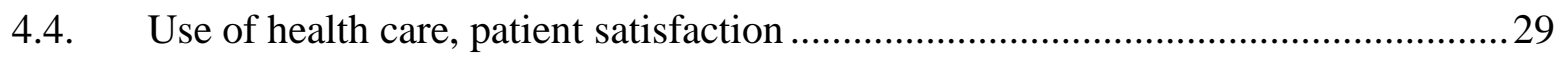

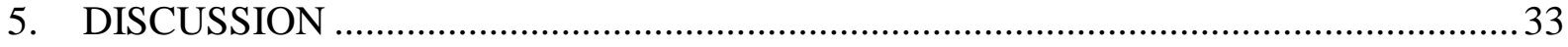

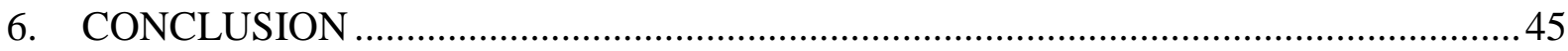

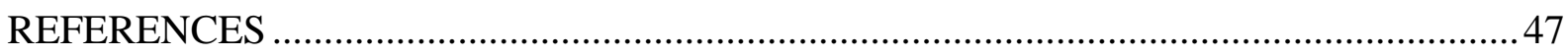

APPENDICES

Magyar nyelvü összefoglaló

Publications I-III. 


\section{LIST OF PUBLICATIONS \\ Publications Related of the Thesis}

I. Nédó Erika, Paulik Edit: Association of smoking, physical activity, and dietary habits with socioeconomic variables: a cross-sectional study in adults on both sides of the Hungarian-Romanian border. BMC Public Health 2012, 12:60 doi:10.1186/1471-245812-60. IF: 2,000

II. Nédó Erika, Paulik Edit: A háziorvosi ellátással való elégedettség mérése a magyar-román határ mentén élők körében. Medicus Universalis, 2012;45:3:97-102.

III. Nédó Erika, Paulik Edit: A védőoltásokkal kapcsolatos ismeretek és attitüdök a magyarromán határ mentén élők körében. Védőnő, 2012. november (közlésre elfogadva)

\section{Abstracts of Congress Presentations Related to the Subject of the Thesis}

1. Nédó Erika: Gyula város egészségügyi alaptérképe. Magyar Higiénikusok Társasága XXXVI. Vándorgyülése, Siófok, 2006. október 3-5. Absztrakt könyv p. 86.

2. Nédó Erika, Paulik Edit: Eating habits by the side of the Hungarian-Romanian border. DKMT, Arad, 2008.

3. Nédó Erika: A magyar és a román lakosság egészségi állapota a határ mentén. Magyar Higiénikusok Társasága XXXVII. Vándorgyűlése, Siófok, 2007. október 2-4. Absztrakt könyv, p. 78.

4. Nédó Erika, Paulik Edit: Inequalities in health damaging behaviours on both sides of the Hungarian-Romanian border. 11th Regional Conference on Environment and Health, Szeged, 2009. május 15-16., Absztrakt CD p. 57.

\section{Other publications}

1. Kovács Eszter, Nédó Erika: Mezőberény város népegészségügyi helyzete. Tisztiorvos, 2001(4):20-23.

2. Nédó Erika: The dwelling environmental characteristics of town Békés. DKMT, Arad, 2007. Konferenciakiadvány 147-152.

3. Nédó Erika: A Réthy Pál Kórház monográfiája. Réthy Pál Kórház-Rendelőintézet, Kolorprint Kft, 2010. (ISBN 978-963-08-0730-2)

4. Nédó Erika: Dr. Réthy (Schlotterbeck) Pál. Orvosi Hetilap 2011;52(36):1459-1461. 
5. Szolnoki Zoltán, Szaniszló István, Szekeres Márta, Hitri Krisztina, Kondacs András, Mándi Yvette, Nédó Erika, Somogyvári Ferenc: Evaluation of the MTHFRA1298C Variant in Leukoaraiosis, J Mol Neurosci. 2012 Mar;46(3):492-6. IF (2011): 2,504 


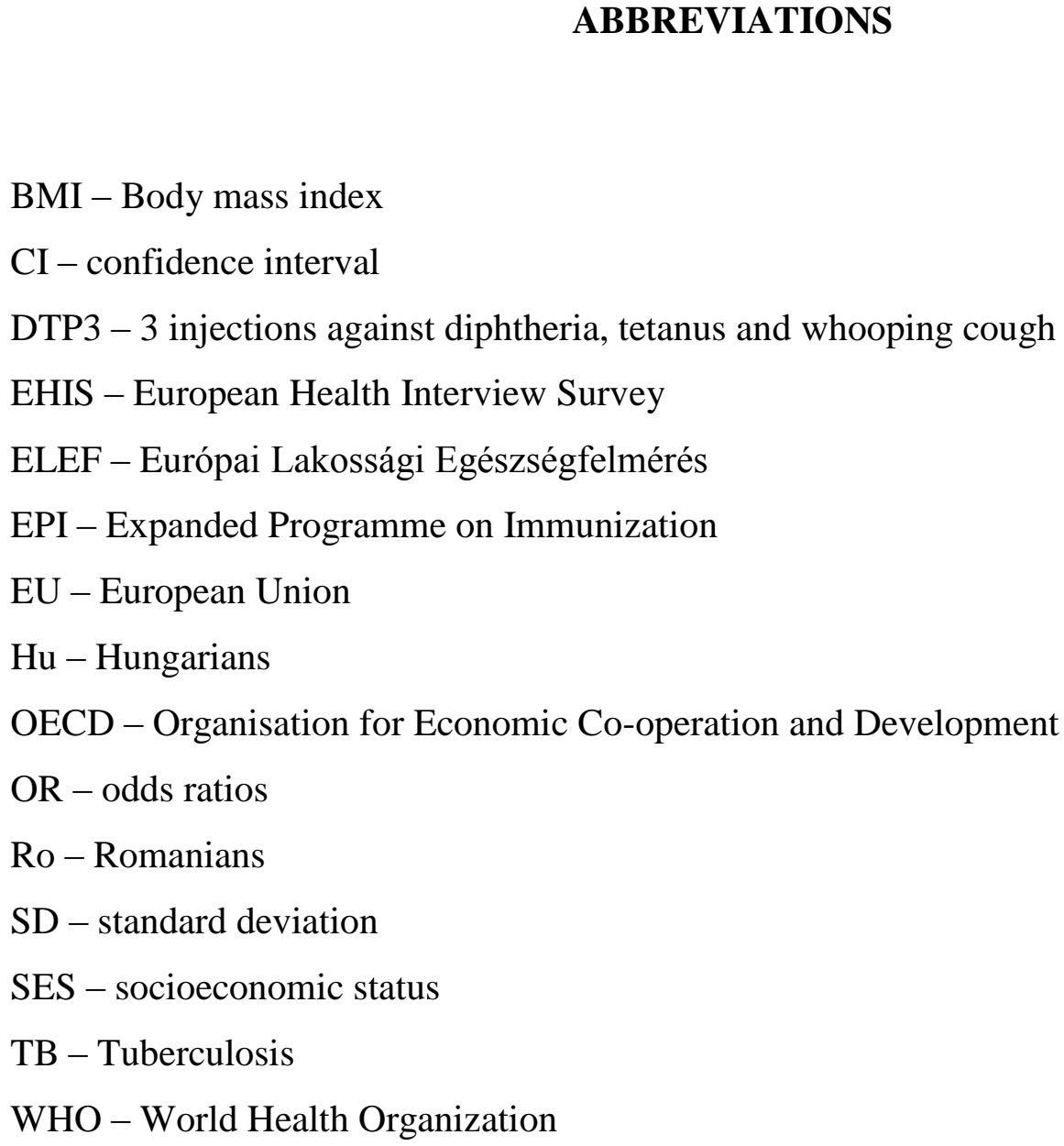

BMI - Body mass index

$\mathrm{CI}$ - confidence interval

DTP3 - 3 injections against diphtheria, tetanus and whooping cough

EHIS - European Health Interview Survey

ELEF - Európai Lakossági Egészségfelmérés

EPI - Expanded Programme on Immunization

EU - European Union

$\mathrm{Hu}$ - Hungarians

OECD - Organisation for Economic Co-operation and Development

OR - odds ratios

Ro - Romanians

$\mathrm{SD}$ - standard deviation

SES - socioeconomic status

TB - Tuberculosis

WHO - World Health Organization 


\section{INTRODUCTION}

Chronic non-communicable diseases are the major cause of death and disability worldwide ${ }^{1}$, and in Europe the greatest disease burden also comes from chronic diseases. ${ }^{2}$

The most prevalent chronic diseases such as heart diseases, tumors, diabetes mellitus etc. are linked by common risk factors such as smoking or unhealthy nutrition, underlying socioeconomic, cultural, political and environmental determinants and opportunities for intervention. These determinants influence health opportunities, health-seeking and lifestyle behaviours as well as onset, expression and outcome of disease. ${ }^{2}$

In a European context, the Eastern European countries (e.g. Hungary, Romania), have worse health status than other countries. Convergence in life expectancy rates between Eastern and Western Europe came to a halt in the 60's and 70's and by the 90's the difference became greater than ever. In 2010, the average life expectancy at birth in Romania 70.1 years among men, and 77.6 years among women, while in Hungary it was 70.7 for men and 78.6 for women. ${ }^{3}$

\section{Romania}

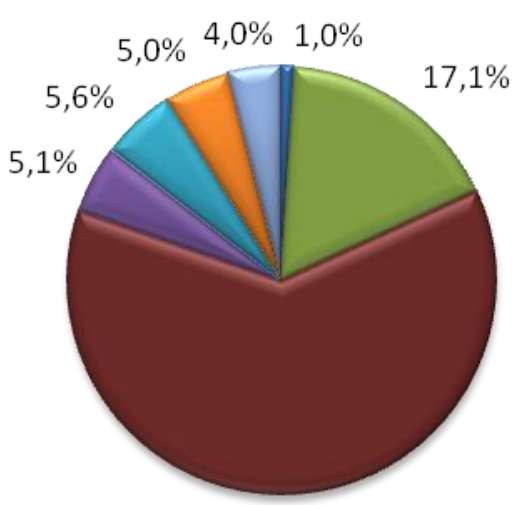

$62,2 \%$

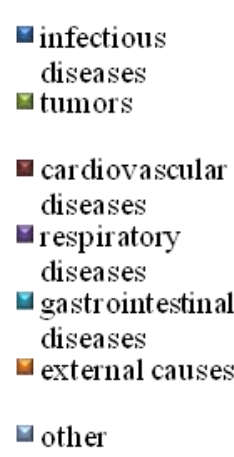

$\square$ other
Hungary

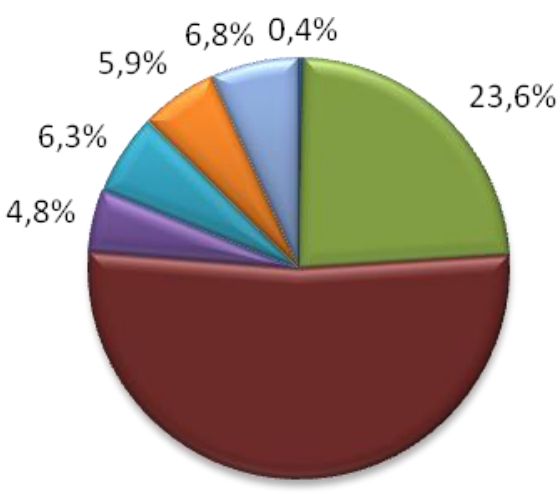

$52,3 \%$

Figure 1 Leading causes of death in Romania and Hungary (2005)

(Based on data from KSH and INDS)

According to statistics in Romania as well as in Hungary (Figure 1) diseases of the circulatory system, including ischemic heart disease and cancer are the main causes of death. ${ }^{4,5}$ Today it is regarded as proven that the individual's health behaviour, way of life and 
also socio- economic situation play a crucial role in the development of these chronic, noncommunicable diseases. ${ }^{6,7,8,9}$

In our study we analyzed the health status of people along the Hungarian-Romanian border. The actuality of the topic was that both countries joined the European Union Hungary (2004), Romania (2007). During the economic transition from centrally planned to free market economy, health promotion programmes require information about the population's current health situation. Getting information about the population's satisfaction with the health care, their health status, health behaviour, habits of using the health services help to determine the necessary improvements. In the future by monitoring changes we can judge the impact and effectiveness of the introduced measures. Today there is an exceptional opportunity for both parties to elaborate common research and project as members of the Danube-KrisMures-Tisa Euroregion, and to establish programs aiming at changing the lifestyle of the population in the region. By identifying the arising health problems on both sides of the border, analyzing the differences and similarities as well as the factors affecting them, we would like to draw attention to the importance of the search for common solutions.

\subsection{Aim of the Study}

The main aim of our research was to study the health situation - including health status, health behaviour and attitudes toward various levels of prevention - of Hungarian and Romanian citizens living on both sides of the border.

The main aim can be achieved by the following steps:

- describing the health status of populations living in Hungary and Romania on sides of the border;

- describing and comparing the prevalence of health damaging behaviours (smoking, unhealthy nutrition, physical inactivity) in the two countries by demographic and socioeconomic characteristics;

- prevention, and exploring the relationship between the recommended vaccine related knowledge, attitudes and socio-demographic characteristics;

- describing the socio-demographic characteristics of participation in the screening tests ;

- surveying the habit of using the healthcare system and satisfaction with health care including especially family doctors. 
In this research work we wanted to focus on the inequalities in health and behaviour from the point of the socioeconomic situation of participants.

Based on the results of the research we determine the common features found in the health status and health behaviour of people living along the border. Upon this a cross-border health promotion programs can be built. We also determine how the opinions and expectations about primary care can be displayed regarding the cross-border health services. Additionally, we wanted to define the target populations of our interventions to promote health among the people living in the two countries so as to support cooperation and development of cross-border community based health promotion programmes on both sides of the Hungarian-Romanian border. 


\section{LITERATURE REVIEW}

\subsection{Measuring health at population level}

The objective measurement of health status is based on the analysis of mortality data. The statistics of the cause of death reflect the population's health status, but they are not sufficient to fully characterize the health-status of the population. For this we need information about the currently existing health problems, including cases of illnesses.

In Hungary we have limited access to morbidity data and they are not reliable because the data collection is based on a registration process. In many countries health surveys provide reliable data about the most widespread diseases.

One of the main objectives of health surveys is to provide information about the health-status of the population. However, depending on how we define the concept of public health, it can be characterized in several ways. The so called biomedical traditional health model where health is interpreted as the absence of disease, has been replaced by a more complex approach, the functional - adaptive model: a person's health can be judged on how he or she can perform a variety of activities and take part in society - including the immediate and wider community - and harmoniously adapt to the environment. ${ }^{10}$

Knowing that individuals view on their own health is a useful measurement of health status, by now the perceived health has become one of the largest general health indicators. Despite the fact that cultural factors significantly influence how a person perceives his or her objective health, and so the comparisons between countries seem quite difficult, surveying perceived health is a recommended method in most international organizations (WHO, EU OECD). ${ }^{11}$ We know it from professional literature how perceived health relates to social status $^{12,13}$, other objective indicators of health and the use of health care.

In the EU countries there are European Public Health Surveys in every 5 years. ${ }^{14}$ Hungary in autumn 2009, this survey was carried out by the Central Statistical Office in 449 settlements among 7000 people who were over 15 years old.

According to the results the population's subjective health sensation improved. $58,9 \%$ of men and $50 \%$ of women felt that their health was good or very good, while $17 \%$ of women and nearly $12 \%$ of men claimed that their health was bad. The answers showed that $2 / 3$ of men and 3/4 of women had chronic illnesses. Most commonly hypertension, locomotor problems, as well as cardiovascular diseases were mentioned. ${ }^{14}$ ELEF dealt with health conditions and lifestyle and also with the utilization of health care system. The result was that 
76 percent of the population regularly, visit their GP, at least once a year. 39 percent visit the doctor only once or twice, but the average is 8 times. ${ }^{14}$

\subsection{Inequalities in health and health behaviour}

There are large variations in the prevalence of chronic diseases among European countries with regard to socioeconomic differences. ${ }^{123}$ The diseases in question, such as heart disease, stroke or diabetes mellitus, have a multifactorial aetiology including individual characteristics and health protective factors, together with social, economic and environmental determinants. $^{2}$

The association of socioeconomic status (SES) with health and health-related behaviours (e.g. smoking, diet and physical activity) has been supported by several epidemiological studies. Smoking is more frequent among lower educated people in developed countries and especially common among the socioeconomically disadvantaged. $15,16,17,18,19,20$ Therefore, tobacco smoking is one of the most important determinants of social inequalities in health in the developed world nowadays. ${ }^{21}$ Unfavourable socioeconomic status is associated not only with tobacco smoking, but with physical inactivity and obesity. Currently, sedentary lifestyle is a severe „epidemic” in the European Union countries. ${ }^{22,23}$ Physical activity has been found to be associated with SES: those with higher educational level or professionals were more likely to be active but maximum at moderate intensity. ${ }^{24}$ Education proved to be associated with indicators of a healthy diet in Norway. ${ }^{25}$ People across Europe with lower SES consume nutrients from a less diverse food base: they eat monotonous diets with little variety. ${ }^{24}$ The connection between socioeconomic and lifestyle factors with overweight and obesity has likewise been confirmed in adult populations. ${ }^{26,27,28}$

The inequalities in health and health-related behaviours can be detected between the Eastern and Western parts of Europe. This „East-West Health Gap”, that is one of the biggest challenges today, is the result of the additive effect of socioeconomic factors and widespread health-damaging behaviours. ${ }^{2,24,29,30,31}$ This problem is especially recognisable in Romania that joined the European Union in 2007, but also in Hungary (EU member since 2004). The health state of the population of Hungary and Romania shows similar trends in mortality. ${ }^{6,32,33,34,35}$ The general state of health of Hungarians and Romanians is worse than justified by the level of their economic development. Life expectancy both in Hungary and in Romania is among the lowest in Europe. ${ }^{32,35,36}$ Furthermore, large variations of life expectancy can be found in different parts of the countries. In case of Hungary, the life 
chances in the Eastern part of the country including the counties situated on the HungarianRomanian border are a great deal worse than that of the population in the Western part of the country. ${ }^{37}$ There are also regional disparities within Romania as regards the health state of the population, e.g. the variation in life expectancy at the county level has shown differences in several areas: the highest is in the counties in the central part of the country, whereas the lower is in the counties in the northern and western parts including the counties on the Hungarian-Romanian border. ${ }^{33}$ On the one hand, there are the similarities in health and geographic conditions and historic events in the neighbouring areas of Romania and Hungary on both sides of the border; on the other hand, there are no data on the similarities and differences in factors influencing health and their relationship with certain demographic and socioeconomic characteristics of the populations in question.

\subsection{Role of prevention in enhancing health at population level}

Prevention is the sum of activities aimed at maintaining and improving health, the earlier diagnosis and treatment of diseases, the extension of human life and premature mortality reduction. This is especially important in case of chronic non-communicable diseases that develop over a long time and during this period and we have the chance of effective intervention. Primary, secondary, and tertiary levels of prevention can be distinguished depending on the stage of health condition or disease we are dealing with. However, it should be emphasized also that the different levels are not isolated from each other. In many respects they form a single system.

Primary health care aims to prevent the disease, preserve and improve health with the help of reducing or terminating the risk and causative factors on individual or population level. This is especially necessary when the disease has not yet manifested.

Secondary prevention is primarily a medical mission. The purpose is the detection of the diseases (screening) if possible at an early stage, when the illness is still reversible. Also includes an effective therapy, the active treatment, which can prevent further progression and complications.

The tertiary prevention occurs when the therapy was inadequate or delayed and therefore complications developed, or in case the long-lasting disease resulted in disability. In that case the patient with the chronic disease has to be treated. It means regular treatment, monitoring and rehabilitation. 


\subsubsection{Primary prevention - vaccinations}

The infectious diseases are constant companions of mankind from the earliest times. The last 200 years of history has shown that the most effective way to prevent and suppress infectious diseases is vaccination.

Thousands of years ago mankind was already aware of the existence of some ,,contagious" diseases from which a person once recovered him or she did not catch it again. We can find the roots of primary immunization in ancient times (variolation). ${ }^{38}$

The first effective vaccination - smallpox vaccination -, which established the principles and practice of vaccination of modern times, was associated with Edward Jenner (1749-1823) British physician. In ten years after the discovery the smallpox vaccination began in Europe. However, in remote areas, such as America, and Asia the distribution of the vaccine was more difficult. Despite the effectiveness of vaccines and vaccination techniques, widespread or mandatory vaccinations spread only slowly, so smallpox epidemics still occurred. England enacted the first vaccination law only in 1840, following a smallpox epidemic which lasted for 3 years and killed more than 41,000 patients. ${ }^{39}$

The WHO declared in 1980 that the world is now completely free from smallpox. After the global eradication of smallpox it was theoretically and practically possible to eradicate other infectious diseases too.

5 years before the smallpox eradication program was successfully completed, in 1974, when the success was already obvious, the Expanded Programme on Immunization (EPI) started and they began to utilize this knowledge. In this programme, in 1992 the great majority of the children on the Earth (over 80\%) were vaccinated against diphtheria, whooping cough, tetanus, polio and measles. By 2010 in three regions (Europe, the Americas, Western Pacific) the vaccination coverage already was $90 \%$ and in the case of DTP3 (at least 3 injection against diphtheria, tetanus and whooping cough) it exceeded $90 \%$ in 130 countries. Consequently the number of infectious diseases and deaths are very strongly reduced: according to calculations each year nearly 3 million deaths are prevented by vaccination against measles, tetanus and whooping cough. ${ }^{40}$ The program is still facing many challenges, because for about 23 million babies worldwide the vaccines are not available. ${ }^{41}$

They simplified the application of vaccines, and reduced the number of them after studies found that it is not necessary to keep long intervals between injections. Thus, the vaccines with different active substances could be administered at the same time. By reviewing the indications and contraindications of the vaccinations, and reducing the number 
of the contraindications, the number of opportunities for vaccination could be increased. During the program, the results of scientific research have improved immunization systems and epidemiological situation in both developing and developed countries. Immunization system in Hungary also utilizes the achievements of the expanded immunization program. ${ }^{42}$ Although the initial idea of a global program was only the marked reduction in the number of infectious diseases, the results provided an excellent foundation for new goals.

During this expanded immunization program WHO aimed to eradicate polio worldwide. Out of WHO's six regions it was American region that became free from contagious polio first in 1994. It was followed by Western Pacific region in 2000 and two years later the European Region in 2002. ${ }^{43}$

Primarily vaccines serve to prevent infectious diseases but in view of the fact that infectious agents play a role in etiology of a number of chronic diseases that are now considered endemic, (e.g. hepatitis B virus - liver cancer, Human Papilloma Virus - cervical cancer), the widespread usage of vaccines implies the possibility of prevention too.

\subsubsection{Secondary prevention - screening}

Screening is for examining healthy or asymptomatic individuals. Its aim is to screen the individual's actual health status, existence of a disease or the lack of it with high accuracy, although the result is not a diagnosis.

Any screening must meet the essential criteria before performing:

- The health condition we are examining must be an important health problem that needs to be closely investigated. We must know about its history from its latent status until it is detected. The stage of the disease should be recognizable latent or early symptomatic.

- There must be an appropriate diagnostic test which is safe and acceptable to the affected population and a reasonable policy, based on test results and national standards, which provides continuous monitoring of the patient's condition.

- There must be an adopted and implemented treatment or intervention for registered patients and for those being in the early stage of a disease or illness. Also the terms and conditions of the treatment must be available. The costs of the exploratory case (including diagnosis and treatment) should be economically balanced regarding possible expenses and the health care as a whole. 
Assessment has to be an integral part of any screening process (simplicity, acceptability, accuracy, cost, reproducibility, sensitivity, specificity).

The potential advantages and disadvantages of screening are summerized in Table $1 .{ }^{44}$

Table 1 Advantages and disadvantages of screening

\begin{tabular}{|c|c|}
\hline Advantages & Disadvantages \\
\hline A better prognosis of found cases. & $\begin{array}{l}\text { Unchanged prognosis may prolong the } \\
\text { disease. }\end{array}$ \\
\hline $\begin{array}{l}\text { In some early detected cases, less radical } \\
\text { treatment is necessary. }\end{array}$ & Overtreatment of questionable abnormalities. \\
\hline Resource savings. & $\begin{array}{l}\text { The costs of screening, resource } \\
\text { requirements. }\end{array}$ \\
\hline $\begin{array}{l}\text { Reassuring people who got negative test } \\
\text { results. }\end{array}$ & $\begin{array}{l}\text { False reassurance for those who have false } \\
\text { negative results. }\end{array}$ \\
\hline & $\begin{array}{l}\text { Anxiety and possible disease awareness of } \\
\text { those with false positive results. } \\
\text { The risks of screening. }\end{array}$ \\
\hline
\end{tabular}

Screening practice is different in Europe because of the structures and the financial systems. In some European countries there is organized, population-wide screening, while in others screening is generally tailored to individuals. Not all countries adhere to international criteria. In many places, the health services belong to the local and regional governments, consequently the practices applied in screening can also be very different. ${ }^{44}$

In Hungary, the national health screening scheme is implemented in the National Health Scheme. Predominantly it is implemented in the outpatient clinics institutional system and it is sector- neutral. The healthcare government has enacted three screening methods based on accumulated experiences gained in many European countries in recent decades.

These are:

- X-raying women aged 45-65 for breast soft tissue (mammograms) every two years.

- Cytological examination using cervical screening for women between the ages of 25 to 65 , which is repeated every three years, as well as

- Screening for occult blood in fecal among men and women between 50-70 by laboratory (immunochemical) examination two-yearly. 
In addition - regarding to the dramatic increase in oral cancer mortality among Hungarian population - has extended occasional oral screenings to men and women between 40-70 years. $^{45}$

\subsection{The use of health care - patient satisfaction}

When assessing the use of health services we should distinguish the population's needs and claims. By the former we mean the standards set out by the experts (such as what value should be treated as high blood pressure), and by the latter we mean what treatment people expect to receive. The two do not necessarily coincide! Some people do not use the benefits of healthcare when even to non-experts it is obvious that they should, while others burden the health care system even with their not health (e.g. social) problems. By using the benefits of health care we mean actual utilization of health services. It means the net result of the interaction between currently emerging public needs and the available services (e.g. how much of the specialist office hours are utilized by the population). ${ }^{46}$

From the late 1970's in developed countries it has been very important to meet patient's expectations and achieve their satisfaction. ${ }^{47,48,49,50}$ Since consumer attitudes are being replaced by customer behaviour, in the last thirty years patient satisfaction had a growing role. ${ }^{51}$ Besides having scientific evidences and experiences an evidence-based health care can gather information about the patients' preferences by questioning the patients' satisfaction and the result can be utilized as a third essential factor. ${ }^{52}$ Patient satisfaction according to the most pragmatic definition - shows the degree of fulfilment of the expectations of the patients. Patients have - consciously or instinctively - expectations of the doctors, the nurses, the care and clinical conditions and generally the performance of the clinic. ${ }^{53}$ There is not always direct relationship between the clinical result and the individual's satisfaction. Some argue that the patient satisfaction in the context of the relationship between care staff and adequate information have a greater impact on them than the professional standard of care they receive.

Patient satisfaction is critical to the success of treatment. If the patient realizes that he or she receives adequate medical treatment, the cooperation between the patient and the doctor is better and the patient will comply with the doctor's advice, instructions, and will be motivated and interested in the treatment. ${ }^{47,54}$ Nowadays the opinion of the patients and their health care satisfaction have become an important indicators of quality. ${ }^{48,55,56}$ In Hungary, the 
first patient satisfaction studies were carried out in the early 1990s. In the past surveys - as well as surveys conducted in recent years - focused on inpatient satisfaction and they less focused on outpatient and home medical care. ${ }^{47,57,58}$ Regarding primary and general medical care that is accessible to all patients, satisfaction is especially important because it has significant influence on the patient's involvement in the whole process of healing, thereby promoting its effectiveness. ${ }^{59}$

The patients' satisfaction with health care is a fundamental indicator of the success of the service which is closely related to the quality of the other two dimensions: the structure and the process. Good quality care cannot be provided without safe equipment, buildings, qualified professionals, and moral and legal rules (structure). ${ }^{55}$ Apart from implementing professionally justified interventions it is also important under what circumstances the patients receive these services. Procedures, care management and the characteristics of the process (e.g: information during healthcare) can also play a decisive role in the evolution of the patient's opinions. ${ }^{47}$

\section{MATERIALS AND METHODS}

\subsection{Study design}

A population-based, cross-sectional health survey was conducted on both sides of the Hungarian-Romanian border (Figure 2), in February to June 2007.

The survey was based on interviewer-administered questionnaires pre-tested on 20 adult persons. Local family practitioners' assistants and midwifes were employed as interviewers after adequate training. Answering the questions was voluntary and anonymous. The study protocol was approved by the Regional and Institutional Human Medical Biological Research Ethics Committee of the University of Szeged (No. 118/2006.). Written informed consent was obtained from each participant of the study. 


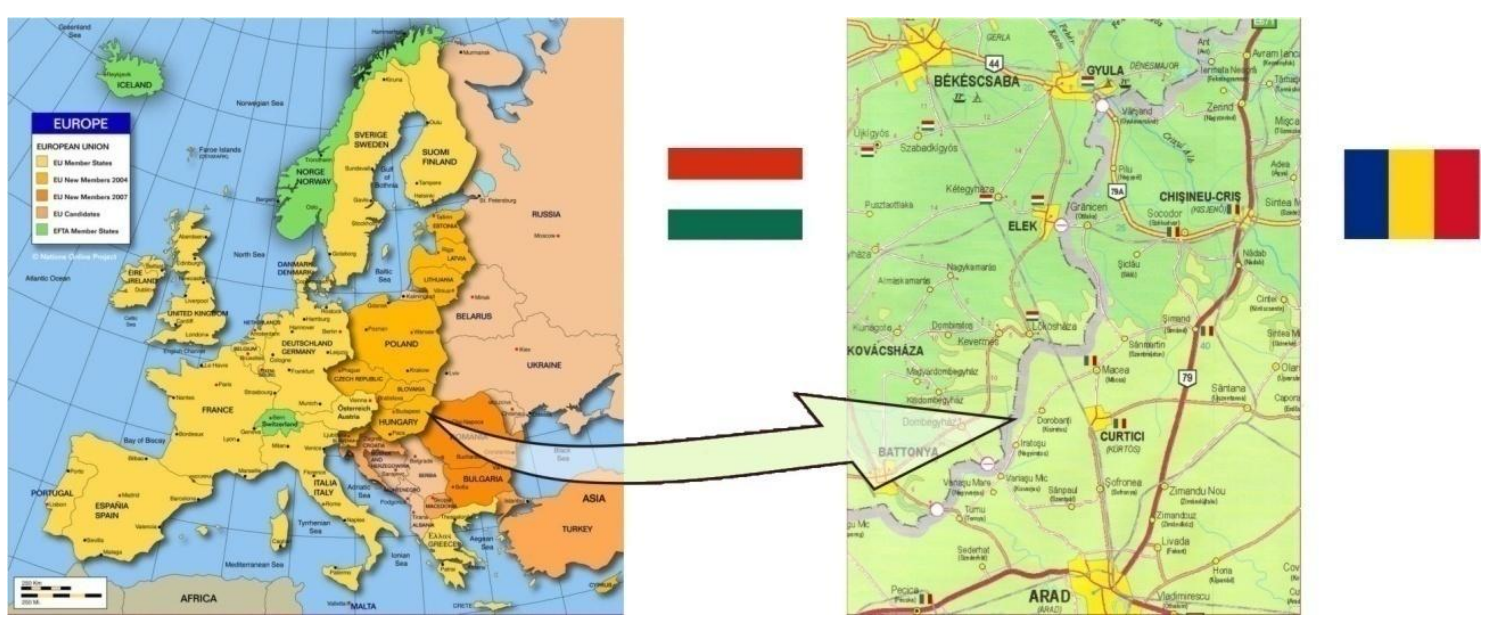

Figure 2 Geographical location of study

\subsection{Population}

A two-stage sampling was used. In the first stage of the sampling, the settlements on both sides of the Hungarian-Romanian border were selected (Table 2). In Hungary, a small area of County Békés, including six settlements (towns and villages), was chosen. Another six settlements in County Arad, with similar characteristics in geographical location and population size, were chosen in Romania. Selecting the settlements for the research was not performed randomly as we involved each settlement from the affected small area in Hungary. Considering the fact that in Romania there are no small areas but mainly larger counties with a higher number of population, we targeted on selecting certain Romanian settlements (matched the settlements) having similar characteristics to the Hungarian settlements involved into the research.

In the second stage, a sample stratified by age and sex was selected randomly from the Hungarian and Romanian citizens aged 18 and over, making use of the local registries. The number of persons picked was proportionate to the population size of the settlements involved in the study. The overall sample of 2,100 people (1,200 Hungarians and 900 Romanians) represented approx. $2 \%$ of the target population. The survey was completed by 1,099 Hungarians and 852 Romanians giving the overall participation rate of $92,9 \%$ (91,6\% for Hungarians $-92,6 \%$ for males and 90,7 for females; $94,7 \%$ for Romanians $-94,9 \%$ for males and $94.4 \%$ for females). 
Table 2 The settlements involved in the study

\begin{tabular}{lcc}
\hline Name of settlement & Type of settlement & Number of inhabitants \\
\hline Gyula & Hungary & \\
Elek & town & 32,355 \\
Kétegyháza & town & 5,462 \\
Lökösháza & large village & 4,373 \\
Szabadkígyós & village & 2,000 \\
Újkígyós & village & 2,940 \\
All & large village & 5,699 \\
\hline & & $\mathbf{5 2 , 8 2 9}$ \\
\hline Chisineu-Cris & Romania & 8,419 \\
Curtici & town & 8,173 \\
Simand & town & 4,307 \\
Socodor & village & 2,273 \\
Macea & village & 6,343 \\
Pecica & village & 12,687 \\
All & village & $\mathbf{4 2 , 2 0 2}$ \\
\hline & &
\end{tabular}

\subsection{Variables}

\subsubsection{Demographic and socio-economic characteristics}

Age, gender, educational level and financial condition were studied as demographic and socioeconomic factors. Educational level was categorized into three classes: low (no school, or primary school only), medium (vocational or secondary school) and high (college or university). Self-perception of financial conditions was based on the following question: „How do you evaluate your financial situation?" The five-point Likert scale - (1) very poor, (2) poor, (3) acceptable, (4) good and (5) very good - was used for the evaluation of selfperceived financial conditions. Because of the low frequency of „very good" and „very poor", the answers were grouped into three categories, ,good" (very good and good), ,,acceptable" and ,poor" (very poor and poor), during the course of the assessment. 
3.3.2. Health status and health behaviour characteristics

Self-reported chronic diseases based on the question „Are you suffering from any chronic disease diagnosed by a doctor?", if ,yes" the disease was specified (osteoporosis, diabetes mellitus, cardiovascular-, gastrointestinal-, endocrinological-, psychiatric-, locomotor-, liver-, kidneys-, and neurological disease).

Self-rated health. The subjects were questioned about their present state of health, and their responses were graded on a five-point scale: very good (5), good (4), average (3), poor (2), and very poor (1).

Body mass index (BMI) was calculated from self-reported body mass $(\mathrm{kg})$ and body height $(\mathrm{m})$ and expressed in $\mathrm{kg} / \mathrm{m}^{2}$. According to the recommendations of the World Health Organization $^{124}$, BMI was grouped into four categories as follows: underweight $(<18.5$ $\left.\mathrm{kg} / \mathrm{m}^{2}\right)$, normal weight $\left(18.5-24.9 \mathrm{~kg} / \mathrm{m}^{2}\right)$, overweight $\left(25.0-29.9 \mathrm{~kg} / \mathrm{m}^{2}\right)$ and obese $(\geq 30.0$ $\mathrm{kg} / \mathrm{m}^{2}$ ). For the purpose of logistic regression BMI-groups were dichotomized as „obesity" $\left(\mathrm{BMI} \geq 30.0 \mathrm{~kg} / \mathrm{m}^{2}\right)$ and ,no obesity" (BMI $\left.<30.0 \mathrm{~kg} / \mathrm{m}^{2}\right)$.

Smoking status was assessed by the question: „Do you smoke?" with the options 'No, I have never smoked regularly', 'No, I have stopped smoking', 'Yes, occasionally', and 'Yes, daily'; the same question with similar options was used in several previous studies. ${ }^{17,18,19,60}$ Smoking status of the respondents was described as never smokers, ex-smokers or current smokers (smoking daily or occasionally) at the time they were interviewed. For the purpose of analysis, smoking status was dichotomized as „smokers" including current smokers, and as „non-smokers" including ex-smokers and never smokers.

Dietary habits were evaluated on the basis of three questions about the frequency of fresh fruit consumption, fresh vegetable consumption and the kind of the fat (vegetable or animal origin) used for cooking. Respondents were asked, e.g. how often they had eaten fresh fruit during the past month with the following options: 'daily, several times', 'at least once a day', '2 to 3 times a week', 'once a week', 'less than once a week' or 'never'. These questions were also used as indicators of healthy diet in the Hungarian „National Health Interview Survey" in $2000 .{ }^{61}$ Diet-related questions used in this survey were compiled by workers of the National Institute for Health Promotion according to the recommendations of the WHO and in accordance with the Hungarian Gallup Organization based on previous Hungarian findings. ${ }^{61}$ On processing the data, these responses were converted into dichotomous variables, the consumption being recorded as „daily" if the answer was 'daily, several times' or 'at least once a day', while all other options were classified as „occasionally or never". In the final analysis, 
„,healthy diet" was recorded when „daily" consumption of fruits, „daily" consumption of vegetables as well as the use of vegetable oil for cooking were recorded, and all the others were categorized as „unhealthy diet".

Subjects were asked to report on their physical activities. Regular participation in competitive sports and leisure-time physical activity was measured. Primarily, those who participated in competitive sports were regarded as physically active persons. People who did not pursue any competitive sport were asked about the regularity of their leisure time physical activity: „How often did you do the following forms of activity (running, swimming, gymnastics or using fitness machines, at least 20 minutes walking, bicycling and gardening) in the last year?" The options were the following: 'once a day', 'several times per week', 'once a week', 'several times per month', 'once a month', 'less than once a month' and 'never'. Those who participated in any form of exercise for less than several times per week (once a week, several times per month, etc.) were regarded as „physically inactive". Physical activity was measured in accordance with the recommendations of WHO and the EU, and questions were set according to the ones used in the Hungarian „National Health Interview Survey" ${ }^{22,63,64}$; the group of questions had already been used but had not been validated.

\subsubsection{Prevention-related characteristics}

\section{Primary prevention - vaccination}

In respect of the vaccinations we examined their importance based on a three point answer scale (important because they prevent diseases; not so important because natural immunity is at least as good; not important at all), knowledge about the recommended vaccinations, and what kind of vaccination would they take willingly, and on what basis would they take it (recommendation of doctors, nurses, health-visitors, friends, the incidence of the disease, the price of the vaccine, and others).

\section{Secondary prevention - screening}

Blood pressure screening. „Do you regularly have your blood pressure measured by your family physician?" answered by 'yes, regularly', 'no, I measure it personally at home', or 'no'.

Cholesterol level screening. The answer alternatives to the question „When has been your cholesterol level checked?" were 'within one year' or 'more than one year before', 'never', 'I don't know'. 
Blood sugar screening. The answer alternatives to the question „When has been your blood sugar level checked?" were 'within one year' or 'more than one year before', 'never', 'I don't know'.

Other screenings. The answer alternatives to the question „When did you participate in the following screenings (chest x-ray, breast screening - mammography, cervical screening)?” were 'within one year' or 'more than one year before', or 'never'.

\subsubsection{Patient satisfaction}

We asked questions about their habits of using the healthcare system. We examined how many times the given person received family doctor care in the 12 months preceding the survey. A Likert scale with 5 grades was used ( $1=$ very dissatisfied, $5=$ very satisfied $)$ for measuring their general satisfaction with health service as well as general and specific satisfaction with GP care. In the case of the latter the assessment was based on 12 aspects (etc. personal relationship, information, availability, waiting time, physical characteristics of the surgery). When composing the list of questions we took into account the questions used in professional international literature for surveying patient satisfaction. ${ }^{14,123}$ We defined the „family doctor satisfaction index” based on the summary of given scores. (minimum: 12 points, maximum: 60 points) and we investigated the context among this index and sociodemographic and health characteristics.

\subsection{Statistical analysis}

Simple descriptive statistics were used to describe the overall characteristics of the sample. To compare the percentages we used Pearson's chi - square test, and in the case of averages we used non-parametric tests (Mann - Whitney and Kruskal - Wallis test). Differences between Hungarians and Romanians were tested by Univariate and multivariate logistic regression models were used to assess the effect of demographic (age, gender) and socioeconomic factors (educational level, financial conditions) on health-related behaviours (smoking, unhealthy diet and physical inactivity) and to reveal the associations between obesity and socioeconomic factors and health-related behaviours in two models. Age in years was introduced as a continuous variable and all other independent factors were included as categorical variables into the logistic regression models. The odds for obesity were adjusted for age, gender, educational level and self-perceived financial conditions in Model 1, and for 
age, gender, educational level, self-perceived financial conditions, smoking status, dietary habits and leisure time physical activity in Model 2. The results are presented as odds ratios (OR) and 95\% confidence intervals $(95 \% \mathrm{CI})$. We considered the result significant in case $\mathrm{p}<0,05$.

While analyzing Logistic Regression associated with vaccinations, the sociodemographic factors (gender, age, and educational level) as independent variables were tested in three binary dependent variables (the importance of immunizations, awareness of recommended immunization and taking vaccinations). The results are presented as odds ratios (OR) and 95\% confidence intervals $(95 \% \mathrm{CI})$. We considered the result significant in case $\mathrm{p}<0,05$.

The data were processed with SPSS 13.0/17.0 for Windows statistical program. 


\section{RESULTS}

\subsection{Demographic characteristics}

The characteristics of the Hungarian and Romanian study population are presented in Table 3. Age and gender distribution was similar (the mean age of the subjects was 48.23 years [SD 18.49; range 18-94] for Hungarians and 47.93 years [SD 17.72; range 18-90] for Romanians). Regarding education and financial conditions, however, there were differences: the rate of those with low education was higher among Romanians, whereas good self-perceived financial conditions were more prevalent among Romanians than Hungarians.

Table 3 Sociodemographic characteristics of the sample by countries

\begin{tabular}{|c|c|c|c|c|c|}
\hline \multirow[t]{2}{*}{ Variables } & \multicolumn{2}{|c|}{$\begin{array}{c}\text { Hungarians } \\
(\mathrm{N}=1099)\end{array}$} & \multicolumn{2}{|c|}{$\begin{array}{c}\text { Romanians } \\
(\mathrm{N}=852)\end{array}$} & \multirow[t]{2}{*}{ P-value ${ }^{1}$} \\
\hline & $\mathrm{n}$ & $\%$ & $\mathrm{n}$ & $\%$ & \\
\hline \multicolumn{5}{|l|}{ Age-groups (yrs) } & 0.866 \\
\hline $18-34$ & 316 & 28.8 & 239 & 28.1 & \\
\hline $35-54$ & 383 & 34.8 & 293 & 34.4 & \\
\hline 55 and over & 400 & 36.4 & 320 & 37.6 & \\
\hline \multicolumn{5}{|l|}{ Gender } & 0.652 \\
\hline Females & 575 & 52.3 & 437 & 51.3 & \\
\hline Males & 524 & 47.7 & 415 & 48.7 & \\
\hline \multicolumn{5}{|l|}{ Educational level } & $<0.001$ \\
\hline High & 197 & 17.9 & 147 & 17.3 & \\
\hline Medium & 550 & 50.0 & 310 & 36.4 & \\
\hline Low & 352 & 32.0 & 395 & 46.4 & \\
\hline \multicolumn{5}{|c|}{ Self-perceived financial conditions } & $<0.001$ \\
\hline Good & 184 & 16.7 & 282 & 33.1 & \\
\hline Acceptable & 634 & 57.7 & 432 & 50.7 & \\
\hline Poor & 281 & 25.6 & 138 & 16.2 & \\
\hline
\end{tabular}

\subsection{Health and health-related behaviours [I]}

In both groups the circulatory and locomotor disorders, sensory problems, and digestive disorders were the most common diseases. Many chronic but not infectious diseases showed a significantly higher proportion among Hungarians (Figure 3).

Considering BMI, the prevalence of obesity was $22.0 \%$ in Hungarians ( $\mathrm{Hu}$ ), and $16.5 \%$ in Romanians (Ro) (Table 4). 


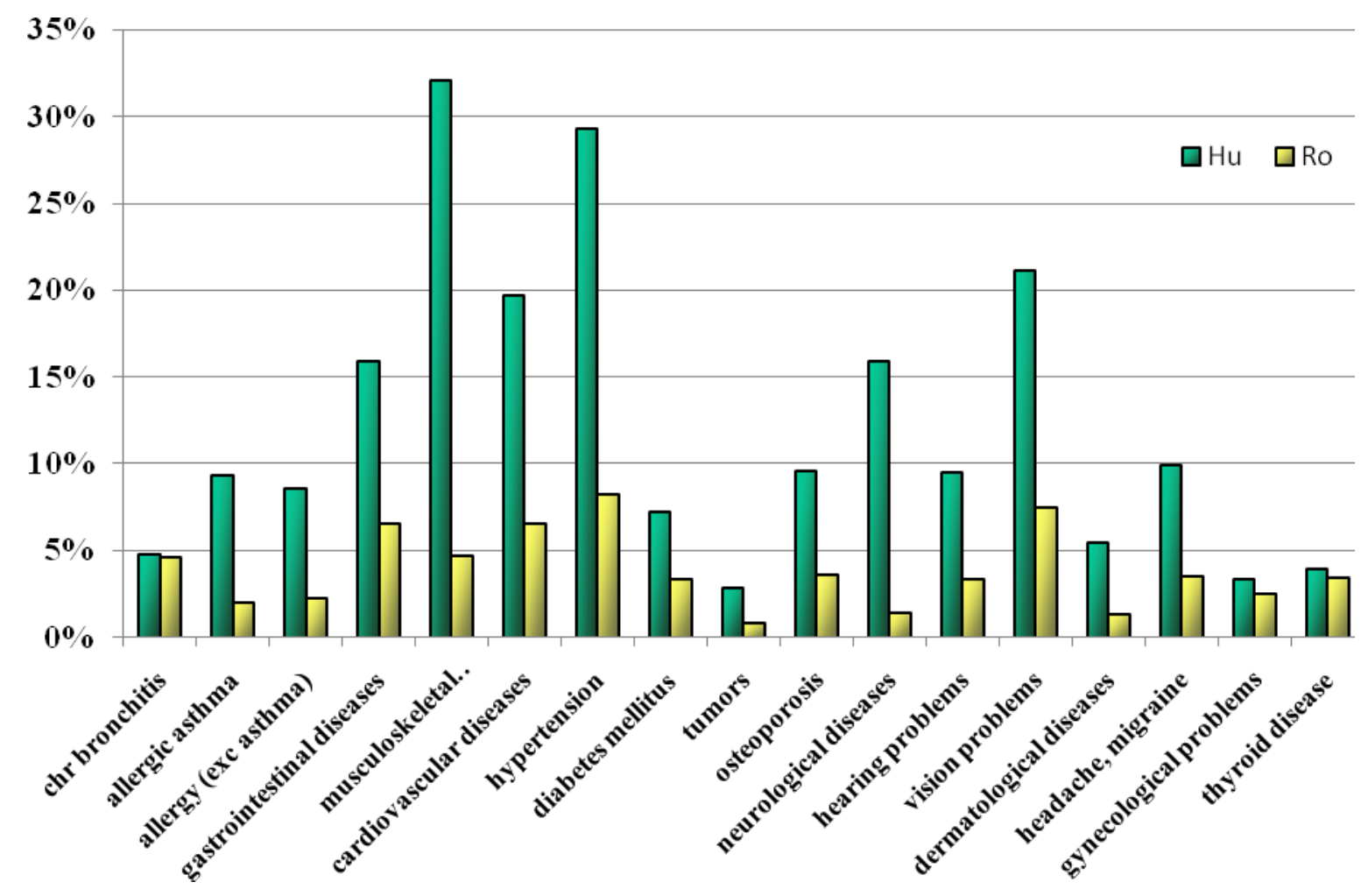

Figure 3 The occurrence of selected chronic diseases by countries

In respect of the subjective evaluation of health status the ,very poor” and ,excellent” ratings percentage was very low in both groups and the most frequently given answer was ,good" (Figure 4).

The self-evaluation of health showed a significantly more favourable picture among the Romanians based on the average values (Hungarian: 3.32; Romanian: 3.48; $\mathrm{p}<0.05$ ). The prevalence of known chronic illnesses shows (Table 4), that the Hungarians had worse (56.4\%) health status than the Romanians (31.1\%).

The subjective assessment of their health conditions correlated with the occurrence of chronic illnesses known by them.

The prevalence of smoking was similar in Hungarians and Romanians (33.2\% and $36.4 \%$ ). The frequency of „daily” fruit and vegetable consumption was lower in Romanians, but regarding the kind of fat used for cooking, no difference was found. The frequency of „unhealthy diet” (as defined in the Methods) was 70.6\% in Hungarians and $75.2 \%$ in Romanians. The frequency of leisure time physical inactivity was more than twice as high in the Romanian (73.2\%) as in the Hungarian (32.0\%) study population (Table 4). 


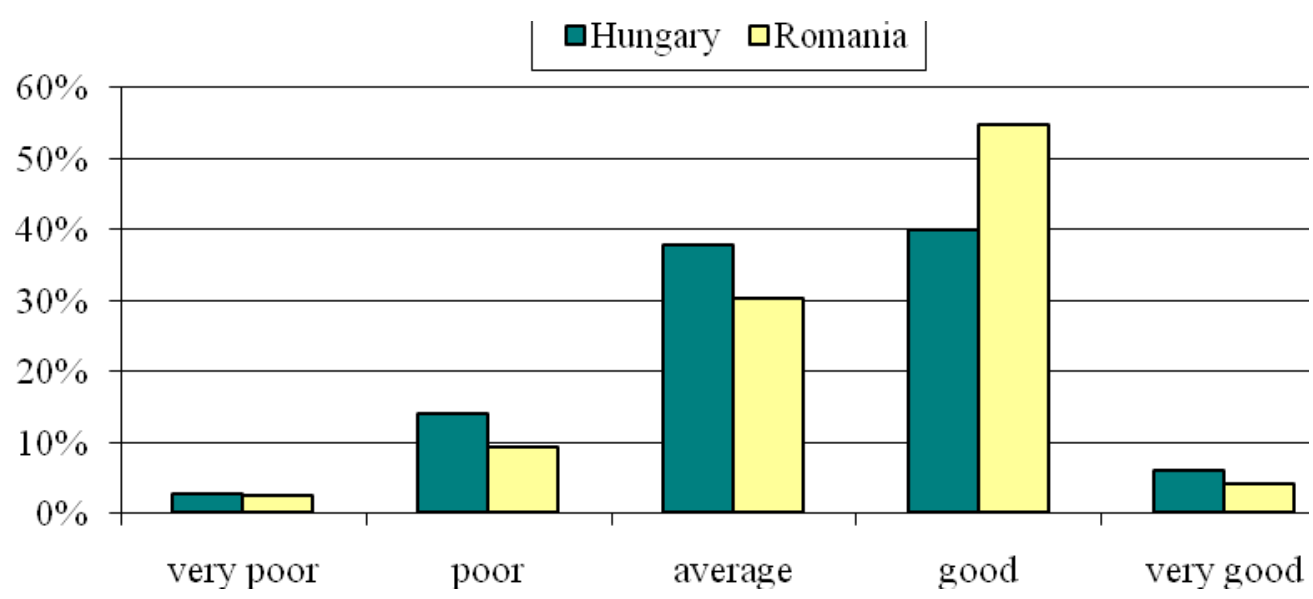

Figure 4 Self-reported health status by countries

Table 4 Chronic diseases prevalence, body mass index and health-related behaviours of the sample by countries

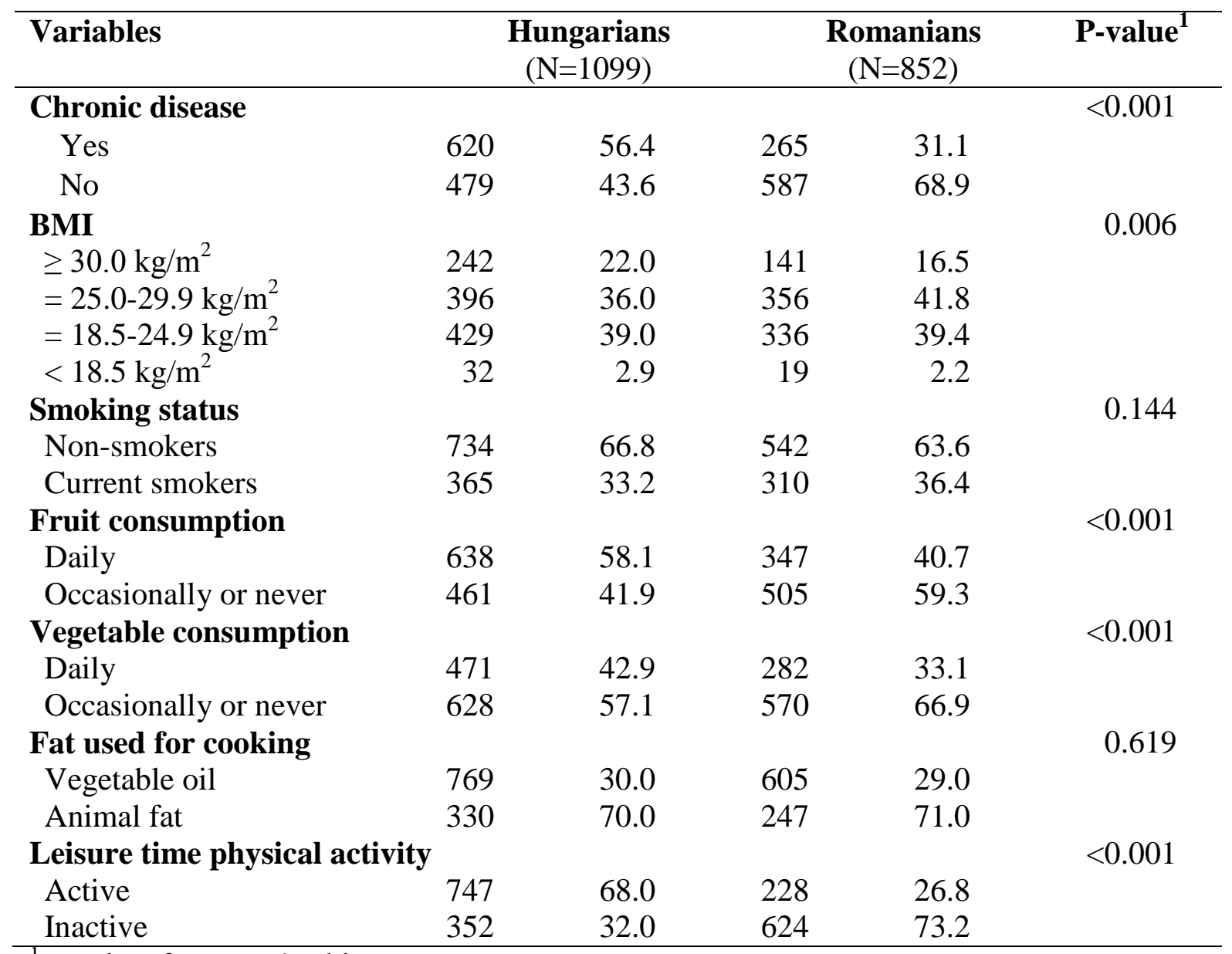

${ }^{1}$ Results of Pearson's chi-square test

BMI: body mass index 
Table 5 Univariate associations of health-related behaviours with demographic and socioeconomic factors

\begin{tabular}{|c|c|c|c|c|c|c|}
\hline \multirow[t]{4}{*}{ Variables } & \multicolumn{6}{|c|}{ Health-related behaviour } \\
\hline & \multicolumn{2}{|c|}{ Smoking } & \multicolumn{2}{|c|}{ Unhealthy diet } & \multicolumn{2}{|c|}{ Leisure time physical inactivity } \\
\hline & Hungarians & Romanians & Hungarians & Romanians & Hungarians & Romanians \\
\hline & OR $(95 \% \mathrm{CI})$ & OR $(95 \% \mathrm{CI})$ & OR $(95 \% \mathrm{CI})$ & OR $(95 \% \mathrm{CI})$ & OR $(95 \% \mathrm{CI})$ & OR $(95 \% \mathrm{CI})$ \\
\hline Age (continuous) & $0.96(0.96-0.97)^{* * * *}$ & $0.98(0.97-0.98)^{* * *}$ & $1.00(0.99-1.01)$ & $1.04(1.03-1.05)^{* * *}$ & $1.00(0.99-1.01)$ & $1.01(0.99-1.02)$ \\
\hline \multicolumn{7}{|l|}{ Gender } \\
\hline Females & 1.00 & 1.00 & 1.00 & 1.00 & 1.00 & 1.00 \\
\hline Males & $2.29(1.78-2.97)^{* * *}$ & $2.89(2.16-3.86)^{* * * *}$ & $2.22(1.69-2.90)^{* * *}$ & $1.75(1.27-2.40)^{* * *}$ & $1.11(0.86-1.43)$ & $0.87(0.64-1.18)$ \\
\hline \multicolumn{7}{|l|}{ Educational level } \\
\hline High & 1.00 & 1.00 & 1.00 & 1.00 & 1.00 & 1.00 \\
\hline Medium & $1.66(1.16-2.38)^{*}$ & $0.61(0.41-0.89)$ & $1.29(0.92-1.82)$ & $1.44(0.97-2.15)$ & $1.04(0.73-1.48)$ & $0.87(0.56-1.35)$ \\
\hline Low & $1.23(0.84-1.82)$ & $0.95(0.64-1.42)$ & $1.77(1.21-2.59)^{* *}$ & $7.91(4.93-12.68)^{* * * *}$ & $1.02(0.69-1.48)$ & $1.02(0.66-1.57)$ \\
\hline \multicolumn{7}{|c|}{ Self-perceived financial conditions } \\
\hline Good & 1.00 & 1.00 & 1.00 & 1.00 & 1.00 & 1.00 \\
\hline Acceptable & $1.43(0.97-2.09)$ & $1.11(0.81-1.52)$ & $1.15(0.81-1.63)$ & $4.08(2.88-5.79)^{* * *}$ & $1.05(0.73-1.49)$ & $0.71(0.50-1.01)$ \\
\hline Poor & $3.13(2.06-4.74)^{* * *}$ & $1.36(0.89-2.07)$ & $2.05(1.35-3.12)^{* *}$ & $4.25(2.52-7.15)^{* * *}$ & $1.21(0.81-1.79)$ & $0.88(0.55-1.42)$ \\
\hline
\end{tabular}

OR: odds ratio; CI: confidence interval ${ }^{*} \mathrm{p}<0.05 ;{ }^{* *} \mathrm{p}<0.01 ;{ }^{* * *} \mathrm{p}<0.001$ 
Tables 5 and 6 present the results of univariate logistic regression models.

Based on these analyses, the risk of smoking decreased by age expressed in years $(\mathrm{ORHu}=0.96,95 \%$ CI: 0.96-0.97; ORRo $=0.98,95 \%$ CI: 0.97-0.98 $)$, and males were more likely to smoke than females $(\mathrm{ORHu}=2.29,95 \% \mathrm{CI}$ : 1.78-2.97; ORRo $=2.89,2.16-3.86)$ both in Hungarians and Romanians. Hungarians with medium educational level (ORHu = 1.66, 95\% CI: 1.16-2.38) and with poor financial conditions (ORHu $=3.13,95 \%$ CI: $2.06-$ 4.74) were more likely to smoke compared to those who were high educated or living in good financial conditions (Table 5).

The risk of unhealthy diet was higher among the elderly (ORRo $=1.04,95 \%$ CI: 1.03 1.05) in Romanians, but there was no association between the consumption of unhealthy diet and age in Hungarians (Table 5). The association between the consumption of unhealthy diet and gender or socio-economic indicators was similar in Hungarians and Romanians: the risk was higher among males $(\mathrm{ORHu}=2.22,95 \% \mathrm{CI}: 1.69-2.90 ;$ ORRo $=1.75,95 \%$ CI: 1.27 $2.40)$, the low educated $(\mathrm{ORHu}=1.77,95 \% \mathrm{CI}: 1.21-2.59$; ORRo $=7.91,95 \%$ CI: 4.93 12.68 ) and those with acceptable (ORRo $=4.08$, 95\% CI: 2.88-5.79) or poor financial conditions $(\mathrm{ORHu}=2.05,95 \% \mathrm{CI}: 1.35-3.12 ; \mathrm{ORRo}=4.25,95 \% \mathrm{CI}: 2.52-7.15)$. None of the socio-economic factors was associated with leisure time physical inactivity in either study population (Table 5), so the factors influencing physical inactivity were not analysed in a multivariate model.

An increased risk of obesity (Table 6) was found among the elderly (ORHu $=1.02$, 95\% CI: 1.01-1.03; ORRo $=1.03,95 \%$ CI: 1.02-1.05) and those with low level of education $(\mathrm{ORHu}=2.43,95 \% \mathrm{CI}: 1.49-3.97 ; \mathrm{ORRo}=2.74,95 \% \mathrm{CI}: 1.48-5.09)$ in both groups and also among medium educated Hungarian respondents $(\mathrm{ORHu}=2.20,95 \% \mathrm{CI}: 1.39-3.53)$. In the univariate analysis conducted in Hungary, obese individuals compared to non-obese were more likely to be non-smokers $(\mathrm{ORHu}=0.65,95 \% \mathrm{CI}: 0.47-0.89)$ and inactive in their leisure time $(\mathrm{ORHu}=1.73,95 \% \mathrm{CI}: 1.29-2.32)$. Romanian subjects who followed an unhealthy diet were more likely to be obese than those following a healthy diet (ORRo $=2.74,95 \%$ CI: 1.61 4.66) (Table 6).

Tables 7 and 8 present the results of multivariate logistic regression models.

Involving all demographic and socioeconomic variables, the associations of healthrelated behaviours with these factors were similar to the results of the univariate analyses, except for the increased risk of smoking among those with poor financial conditions in Romania (ORRo $=1.72,95 \%$ CI: 1.07-2.77) $($ Table 7). 
Table 6 Univariate associations of obesity (BMI $\geq 30 \mathrm{~kg} / \mathrm{m}^{2}$ ) with demographic, socioeconomic factors and health-related behaviours by countries

\begin{tabular}{|c|c|c|}
\hline Variables & $\begin{array}{l}\text { Hungarians } \\
\text { OR }(95 \% \mathrm{CI})\end{array}$ & $\begin{array}{c}\text { Romanians } \\
\text { OR }(95 \% \mathrm{CI})\end{array}$ \\
\hline Age (continuous) & $1.02(1.01-1.03)^{* * *}$ & $1.03(1.02-1.05)^{\text {**** }}$ \\
\hline \multicolumn{3}{|l|}{ Gender } \\
\hline Females & 1.00 & 1.00 \\
\hline Males & $1.03(0.78-1.38)$ & $1.01(0.70-1.45)$ \\
\hline \multicolumn{3}{|l|}{ Educational level } \\
\hline High & 1.00 & 1.00 \\
\hline Medium & $2.20(1.39-3.53)^{* * *}$ & $1.75(0.91-3.36)$ \\
\hline Low & $2.43(1.49-3.97)^{* * *}$ & $2.74(1.48-5.09)^{* *}$ \\
\hline \multicolumn{3}{|c|}{ Self-perceived financial conditions } \\
\hline Good & 1.00 & 1.00 \\
\hline Acceptable & $1.11(0.74-1.68)$ & $1.17(0.77-1.76)$ \\
\hline Poor & $1.39(0.88-2.19)$ & $1.11(0.64-1.93)$ \\
\hline \multicolumn{3}{|l|}{ Smoking status } \\
\hline Non-smokers & 1.00 & 1.00 \\
\hline Current smokers & $0.65(0.47 ; 0.89)^{* *}$ & $0.82(0.56 ; 1.20)$ \\
\hline \multicolumn{3}{|l|}{ Dietary habits } \\
\hline Healthy diet & 1.00 & 1.00 \\
\hline Unhealthy diet & $1.06(0.77 ; 1.45)$ & $2.74(1.61 ; 4.66)^{* * *}$ \\
\hline \multicolumn{3}{|c|}{ Leisure time physical activity } \\
\hline Active & 1.00 & 1.00 \\
\hline Inactive & $1.73(1.29 ; 2.32)^{* * *}$ & $0.68(0.46 ; 1.01)$ \\
\hline
\end{tabular}

OR: odds ratio; CI: confidence interval; BMI: body mass index

${ }^{*} \mathrm{p}<0.05 ;{ }^{* *} \mathrm{p}<0.01 ;{ }^{* * *} \mathrm{p}<0.001$

Including only demographic and socioeconomic factors into the multivariate model of obesity (Model 1), the risk of obesity was increased with age by years $(\mathrm{ORHu}=1.02,95 \%$ CI: 1.01-1.03; ORRo $=1.03,95 \%$ CI: 1.02-1.05) both in Hungarians and Romanians and was higher among those with medium educational level $(\mathrm{ORHu}=2.09,95 \% \mathrm{CI}: 1.29-3.37)$ in Hungarians (Table 8). Involving health-related behaviours (Model 2), the effects of age and education were not changed. The impact of behaviours was different by nations. On the one hand, obesity was found to be positively associated with unhealthy diet only in Romanians $($ ORRo $=2.10,95 \%$ CI: 1.18-3.75); on the other hand, physically inactive Hungarians were more $(\mathrm{ORHu}=1.74,95 \% \mathrm{CI}: 1.28-2.36)$, whereas inactive Romanians were less $(\mathrm{ORRo}=$ 0.64, 95\% CI: 0.42-0.96) likely to be obese than physically active people from the same country. In Hungarians, the association between smoking and obesity was attenuated after controlling for all variables. 
Table 7 Multivariate associations of health-related behaviours with demographic and socioeconomic factors by countries

\begin{tabular}{|c|c|c|c|c|}
\hline \multirow[t]{4}{*}{ Variables } & \multicolumn{4}{|c|}{ Health-related behaviour } \\
\hline & \multicolumn{2}{|c|}{ Smoking } & \multicolumn{2}{|c|}{ Unhealthy diet } \\
\hline & Hungarians & Romanians & Hungarians & Romanians \\
\hline & OR $(95 \% \mathrm{CI})$ & OR $(95 \% \mathrm{CI})$ & OR $(95 \% \mathrm{CI})$ & OR $(95 \% \mathrm{CI})$ \\
\hline Age (continuous) & $0.96(0.95-0.97)^{* * *}$ & $0.98(0.97-0.99)^{* * *}$ & $0.99(0.99-1.00)$ & $1.02(1.01-1.03)^{* * *}$ \\
\hline \multicolumn{5}{|l|}{ Gender } \\
\hline Females & 1.00 & 1.00 & 1.00 & 1.00 \\
\hline \multicolumn{5}{|l|}{ Educational level } \\
\hline High & 1.00 & 1.00 & 1.00 & 1.00 \\
\hline Medium & $1.36(0.92-2.01)$ & $0.97(0.63-1.49)$ & $1.11(0.79-1.59)$ & $1.01(0.65-1.56)$ \\
\hline Low & $1.59(1.01-2.51)^{*}$ & $0.76(0.47-1.22)$ & $1.63(1.06-2.51)^{*}$ & $3.58(2.08-6.15)^{\text {**** }}$ \\
\hline \multicolumn{5}{|c|}{ Self-perceived financial conditions } \\
\hline Good & 1.00 & 1.00 & 1.00 & 1.00 \\
\hline
\end{tabular}

OR: odds ratio; CI: confidence interval

${ }^{*} \mathrm{p}<0.05 ;{ }^{* *} \mathrm{p}<0.01 ;{ }^{* * *} \mathrm{p}<0.001$ 
Table 8 Multivariate associations of obesity $\left(\mathrm{BMI} \geq 30 \mathrm{~kg} / \mathrm{m}^{2}\right)$ with demographic, socioeconomic factors and health-related behaviours

\begin{tabular}{|c|c|c|c|c|}
\hline \multirow[t]{3}{*}{ Variables } & \multicolumn{2}{|c|}{ Model 1} & \multicolumn{2}{|c|}{ Model 2} \\
\hline & Hungarians & Romanians & Hungarians & Romanians \\
\hline & OR $(95 \% \mathrm{CI})$ & OR $(95 \% \mathrm{CI})$ & OR $(95 \% \mathrm{CI})$ & OR $(95 \% \mathrm{CI})$ \\
\hline Age (continuous) & $1.02(1.01-1.03)^{* * * *}$ & $1.03(1.02-1.05)^{* * *}$ & $1.02(1.01-1.03)^{* * *}$ & $1.03(1.02 ; 1.04)^{* * *}$ \\
\hline \multicolumn{5}{|l|}{ Gender } \\
\hline Females & 1.00 & 1.00 & 1.00 & 1.00 \\
\hline Males & $1.10(0.81-1.47)$ & $1.01(0.69-1.46)$ & $1.15(0.84-1.56)$ & $0.93(0.63-1.38)$ \\
\hline \multicolumn{5}{|l|}{ Educational level } \\
\hline High & 1.00 & 1.00 & 1.00 & 1.00 \\
\hline Medium & $2.09(1.29-3.37)^{* *}$ & $1.53(0.78-3.01)$ & $2.16(1.33-3.50)^{* *}$ & $1.47(0.74-2.89)$ \\
\hline Low & $1.57(0.92-2.68)$ & $1.55(0.77-3.13)$ & $1.66(0.97-2.84)$ & $1.35(0.66-2.76)$ \\
\hline \multicolumn{5}{|c|}{ Self-perceived financial conditions } \\
\hline Good & 1.00 & 1.00 & 1.00 & 1.00 \\
\hline Acceptable & $1.02(0.67-1.57)$ & $0.89(0.57-1.39)$ & $1.04(0.67-1.59)$ & $0.78(0.49-1.23)$ \\
\hline Poor & $1.25(0.78-2.02)$ & $0.88(0.49-1.60)$ & $1.31(0.81-2.14)$ & $0.79(0.43-1.45)$ \\
\hline \multicolumn{5}{|l|}{ Smoking status } \\
\hline Non-smokers & & & 1.00 & 1.00 \\
\hline Current smokers & & & $0.70(0.49 ; 1.00)$ & $1.03(0.67 ; 1.57)$ \\
\hline \multicolumn{5}{|l|}{ Dietary habits } \\
\hline Healthy diet & & & 1.00 & 1.00 \\
\hline Unhealthy diet & & & $0.99(0.71 ; 1.38)$ & $2.10(1.18 ; 3.75)^{*}$ \\
\hline \multicolumn{5}{|c|}{ Leisure time physical activity } \\
\hline Active & & & 1.00 & 1.00 \\
\hline Inactive & & & $1.74(1.28 ; 2.36)^{* * * *}$ & $0.64(0.42 ; 0.96)^{*}$ \\
\hline
\end{tabular}

BMI: body mass index; OR: odds ratio; CI: confidence interval; ${ }^{*} \mathrm{p}<0.05 ;{ }^{* *} \mathrm{p}<0.01 ;{ }^{* * *} \mathrm{p}<0.001$

Covariates in Model 1: age, gender, educational level and self-perceived financial conditions.

Covariates in Model 2: age, gender, educational level, self-perceived financial conditions, smoking status, dietary habits and leisure time physical activity. 


\subsection{Prevention}

\subsubsection{Attitudes toward vaccination [III.]}

After analyzing the vaccination related knowledge and attitudes of the countries, significant differences were found in the Romanian and Hungarian groups. Those who think vaccination is very important and also those who think it is not important at all appeared in a bigger proportion among the Romanians (Table 9).

Table 9 Attitudes towards vaccinations by countries

\begin{tabular}{|c|c|c|c|c|c|}
\hline \multirow{2}{*}{$\begin{array}{l}\text { Variables } \\
\text { Importance of vaccines }\end{array}$} & \multicolumn{2}{|c|}{$\begin{array}{l}\text { Hungary } \\
(\mathrm{N}=1099)\end{array}$} & \multicolumn{2}{|c|}{$\begin{array}{c}\text { Romania } \\
(\mathrm{N}=\mathbf{8 5 2})\end{array}$} & \multirow{2}{*}{$\begin{array}{r}\text { P- value } \\
<0.001\end{array}$} \\
\hline & & & & & \\
\hline $\begin{array}{l}\text { Important because they prevent } \\
\text { diseases. }\end{array}$ & 827 & 75.3 & 669 & 78.5 & \\
\hline $\begin{array}{l}\text { They are not so important because } \\
\text { the natural immunity is at least as } \\
\text { good. }\end{array}$ & 226 & 20.6 & 120 & 14.1 & \\
\hline They are not important at all. & 46 & 4.2 & 63 & 7.4 & \\
\hline $\begin{array}{l}\text { Knowledge about recommended } \\
\text { vaccinations }\end{array}$ & & & & & $<0.001$ \\
\hline Yes & 936 & 85.2 & 275 & 32.3 & \\
\hline No & 163 & 14.8 & 577 & 67.7 & \\
\hline Taking recommended immunization & & & & & $<0.001$ \\
\hline Yes & 531 & 48.3 & 484 & 56.8 & \\
\hline No & 568 & 51.7 & 368 & 43.2 & \\
\hline
\end{tabular}

The Hungarians have heard of the recommended vaccines in a much higher rate than the Romanians ( $85.2 \%$ vs. $32.3 \%$ ), and this difference was reflected in the number of diseases - that can be prevented with non-compulsory vaccination - which they could name. Among Hungarians more people knew that vaccination is recommended for the following diseases: influenza, pneumonia, hepatitis, encephalitis, tick-borne encephalitis, and chickenpox. The Romanians practically knew only about the flu vaccine. Only few people marked the rest of the illnesses. In both groups there were only a few people who could name diseases in connection with age-related mandatory vaccinations (e.g. BCG) that are preventable with recommended injections. 
Table 10 A védőoltásokkal kapcsolatos véleményeket befolyásoló szociodemográfiai tényezők (többváltozós logisztikus regresszió)

\begin{tabular}{|c|c|c|c|c|c|c|}
\hline \multirow[t]{2}{*}{ Variables } & \multicolumn{2}{|c|}{ Importance of vaccinations } & \multicolumn{2}{|c|}{$\begin{array}{l}\text { Knowledge about recommended } \\
\text { vaccinations }\end{array}$} & \multicolumn{2}{|c|}{$\begin{array}{l}\text { Taking recommended } \\
\text { vaccinations }\end{array}$} \\
\hline & OR & $95 \% \mathrm{CI}$ & OR & $95 \% \mathrm{CI}$ & OR & $95 \% \mathrm{CI}$ \\
\hline \multicolumn{7}{|l|}{ Gender } \\
\hline Female & $1.28^{*}$ & $1.03-1.59$ & $1.29^{*}$ & $1.03-1.62$ & $1.29^{* * *}$ & $1.08-1.55$ \\
\hline Male & 1.00 & & 1.00 & & 1.00 & \\
\hline \multicolumn{7}{|l|}{ Age groups } \\
\hline 18-34 years & $1.52^{* *}$ & $1.13-2.04$ & 0.75 & $0.55-1.02$ & 0.80 & $0.63-1.02$ \\
\hline $35-54$ years & 0.98 & $0.76-1.27$ & 0.81 & $0.61-1.08$ & 0.89 & $0.72-1.13$ \\
\hline 55 and older & 1.00 & & 1.00 & & 1.00 & \\
\hline \multicolumn{7}{|l|}{ Level of education } \\
\hline Higher education & $1.56^{* *}$ & $1.22-2.00$ & $2.73^{* * * *}$ & $2.09-3.57$ & $1.49^{* * * *}$ & $1.21-1.86$ \\
\hline Secondary education & $2.19^{* * *}$ & $1.54-3.12$ & $6.01^{* * * *}$ & $4.16-8.67$ & $2.67^{* * * *}$ & $2.00-3.55$ \\
\hline Primary education & 1.00 & & 1.00 & & 1.00 & \\
\hline \multicolumn{7}{|l|}{ Residence } \\
\hline Romania & $1.31^{*}$ & $1.05-1.63$ & $0.08^{* * * *}$ & $0.06-0.09$ & $1.52^{* * * *}$ & $1.26-1.82$ \\
\hline Hungary & 1.00 & & 1.00 & & 1.00 & \\
\hline
\end{tabular}

OR: odds ratio; CI: confidence interval

${ }^{*} \mathrm{p}<0.05 ;{ }^{* *} \mathrm{p}<0.01 ;{ }^{* * *} \mathrm{p}<0.001$ 
When asked whether they would buy recommended vaccinations Romanians were more likely to respond positively, (Table 9) but in both groups the doctor has the greatest effect on the decision concerning the uptake of the recommended vaccination. Among Hungarians, the second most important aspect was recommendation from the nurse and the third was the severity of the illness, while among Romanians it was the opposite. The price of the vaccine and nurse recommendation proved to be less determining.

The vaccine-related knowledge and attitudes was analysed (Table 10) by multivariate logistic regression analysis. It showed that the chance that they find vaccination important was bigger among women (OR: 1.28), 18-34 year olds OR: 1.52), secondary (OR: 2.19), and higher education (OR: 1.56) graduates, and those living in Romania (OR: 1.31). The recommended vaccines were more likely to be known by the women (OR: 1.29), those with higher education $(\mathrm{OR}=6.01$ and 2.73) and Hungarians (OR: 1.00). The chance of recommended vaccination uptake was larger for women (OR: 1.29), (those with higher qualification OR 2.67 and 1.49) and among Romanians (OR:1.52).

\subsubsection{Screening}

Very high proportion of Romanian people have never measured their cholesterol or blood sugar levels (see Table 11).

Table 11 Frequency of blood pressure, serum cholesterol and blood sugar measurements by countries

\begin{tabular}{|c|c|c|c|c|c|}
\hline \multirow{2}{*}{$\begin{array}{l}\text { Variables } \\
\text { Blood pressure }\end{array}$} & \multicolumn{2}{|c|}{$\begin{array}{l}\text { Hungary } \\
(\mathrm{N}=1099)\end{array}$} & \multicolumn{2}{|c|}{$\begin{array}{c}\text { Romania } \\
(\mathrm{N}=852)\end{array}$} & \multirow{2}{*}{$\begin{array}{c}\text { P-value }^{1} \\
<0.001\end{array}$} \\
\hline & & & & & \\
\hline $\begin{array}{l}\text { Regularly measured by family } \\
\text { physician }\end{array}$ & 417 & 37.9 & 454 & 53.3 & \\
\hline Self-measurement at home & 325 & 29.6 & 137 & 16.1 & \\
\hline Not measured regularly & 357 & 32.5 & 261 & 30.6 & \\
\hline Cholesterol level & & & & & $<0.001$ \\
\hline Measured within one year & 511 & 46.5 & 299 & 35.1 & \\
\hline $\begin{array}{l}\text { Measured more than one year } \\
\text { before }\end{array}$ & 265 & 24.1 & 116 & 13.6 & \\
\hline Never/don't know & 323 & 29.4 & 437 & 51.3 & \\
\hline Blood sugar & & & & & $<0.001$ \\
\hline Measured within one year & 586 & 53.3 & 301 & 35.3 & \\
\hline $\begin{array}{l}\text { Measured more than one year } \\
\text { before }\end{array}$ & 298 & 27.1 & 106 & 12.4 & \\
\hline Never/don't know & 215 & 19.6 & 445 & 52.2 & \\
\hline
\end{tabular}

${ }^{1}$ Results of Pearson's chi-square test 
Table 12 shows some other results of the use of screening with important public health significance.

Table 12 Participation in various screening procedures by nations

\begin{tabular}{|c|c|c|c|c|c|}
\hline \multirow{2}{*}{$\begin{array}{l}\text { Variables } \\
\text { Chest x-ray (males+females) }\end{array}$} & \multicolumn{2}{|c|}{ Hungary } & \multicolumn{2}{|c|}{ Romania } & \multirow{2}{*}{$\frac{\text { P-value }^{3}}{<0.001}$} \\
\hline & & & & & \\
\hline Measured within one year & 417 & 37.9 & 454 & 53.3 & \\
\hline Measured more than one year before & 325 & 29.6 & 137 & 16.1 & \\
\hline Never measured & 357 & 32.5 & 261 & 30.6 & \\
\hline Breast screening (females) ${ }^{2}$ & & & & & $<0.001$ \\
\hline Measured within one year & 511 & 46.5 & 299 & 35.1 & \\
\hline Measured more than one year before & 265 & 24.1 & 116 & 13.6 & \\
\hline Never measured & 323 & 29.4 & 437 & 51.3 & \\
\hline Cervical screening (females) ${ }^{2}$ & & & & & $<0.001$ \\
\hline Measured within one year & 586 & 53.3 & 301 & 35.3 & \\
\hline Measured more than one year before & 298 & 27.1 & 106 & 12.4 & \\
\hline Never measured & 215 & 19.6 & 445 & 52.2 & \\
\hline
\end{tabular}

\subsection{Use of health care, patient satisfaction [II.]}

In relation to health care utilization, we found that $86,1 \%$ of the Hungarians, and the $82 \%$ of Romanians turn to their GP first if they need medical help.

However there was a significant difference between the Hungarian and Romanian group regarding the percentage turning to a family doctor in the year preceding the examination: Hungarians $(83,3 \%)$ visited their GP in a substantially higher proportion than Romanians $(66,8 \%)$.

Table 13 Frequency of visiting the family doctor by countries

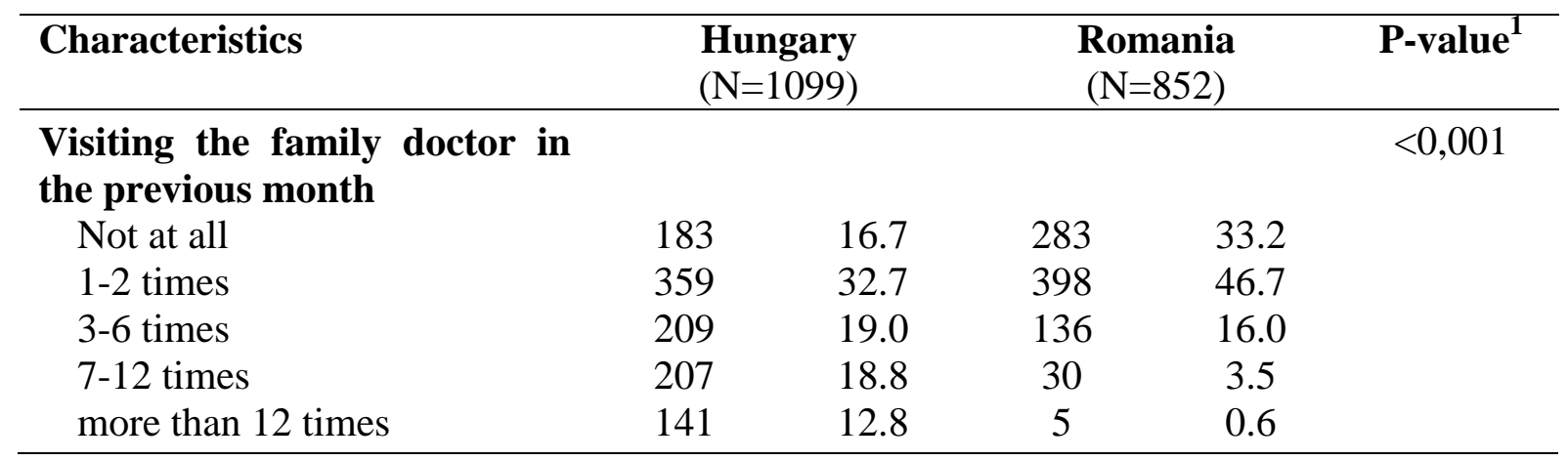

\footnotetext{
${ }^{1}$ Results of Pearson's chi-square test
} 
There was also difference in the number of how many times they visited their GP. The number of those who turned to the GP three or more times was higher among Hungarians.

There was no difference in the global health care satisfaction on average between the two countries (Hungarian: $3.37 \pm 0.91$; Romanians: $3.36 \pm 0.88$ ).

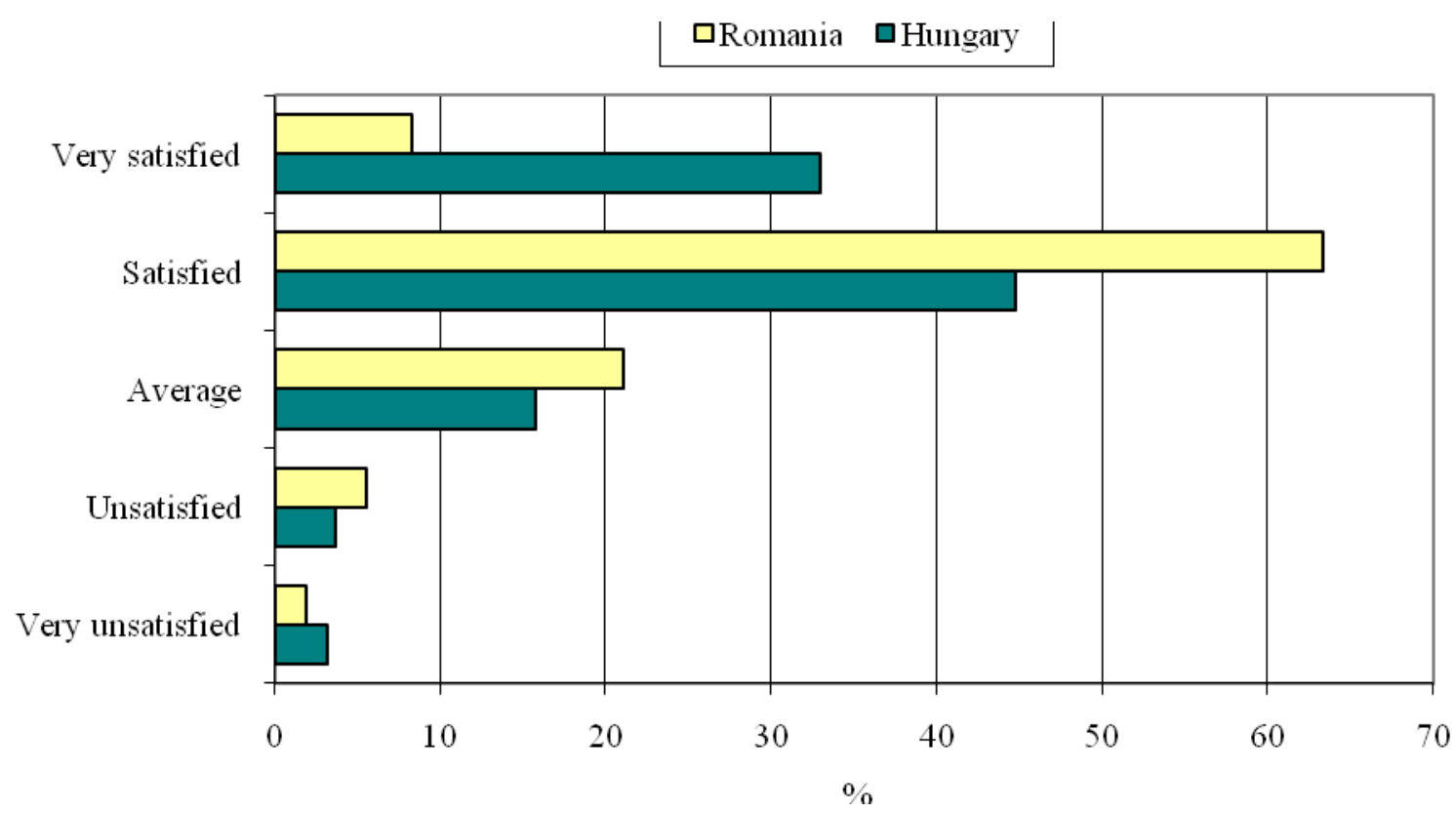

Figure 5: Overall satisfaction with home medical care by countries

$77.6 \%$ of Hungarians and $71.6 \%$ of Romanians were satisfied or very satisfied with their GP (Figure 5). Based on the average value of the score, the Hungarians (4.01 \pm 0.95$)$ were significantly more satisfied with the family doctor care, than the Romanians (3.71 \pm 0.77$)$.

Patients gave their opinions regarding their satisfaction on each component of the family doctor care. It is summarized on average score in Table 14.

Except for two criteria (booking system and the waiting time), there was significant difference in opinions, and generally found that the Hungarians were significantly more satisfied with their care than the Romanians. In the case of Hungarians there was more significant difference in the ranking regarding the satisfaction with certain characteristics. They were mostly satisfied with physical environment (office cleanliness, geographical accessibility, facilities) while the biggest problem is the waiting time. In the ranking it was followed by the booking system and the lack of the opportunity of private consultation with the GP. In the case of the Romanians, however, the difference was minimal in their score given to each questions, so in their case, the hierarchy was less explicit. Romanians were most 
satisfied with the opportunity of private consultation with the GP, and surgery hours and they were less satisfied with the condition of the waiting room and the long waiting time.

Table 14 Satisfaction with specific characteristics of family care by countries

\begin{tabular}{|c|c|c|c|}
\hline \multirow[t]{2}{*}{ Characteristics } & Hungary & Romania & \multirow[t]{2}{*}{ P-value ${ }^{1}$} \\
\hline & average $\pm \mathrm{SD}$ & average $\pm \mathrm{SD}$ & \\
\hline Amount of time spent on your care & $3.91 \pm 0.94$ & $3.55 \pm 0.94$ & $<0.001$ \\
\hline $\begin{array}{l}\text { Information from GP reagarding your } \\
\text { health }\end{array}$ & $3.95 \pm 0.91$ & $3.67 \pm 0.88$ & $<0.001$ \\
\hline $\begin{array}{l}\text { Information about recommended } \\
\text { lifestyle }\end{array}$ & $3.82 \pm 0.99$ & $3.67 \pm 0.90$ & $<0.001$ \\
\hline $\begin{array}{l}\text { Opportunity of private consultation } \\
\text { with the GP }\end{array}$ & $3.79 \pm 1.08$ & $3.77 \pm 0.96$ & 0.018 \\
\hline The availability of GP (e.g. phone) & $4.01 \pm 0.96$ & $3.73 \pm 0.91$ & $<0.001$ \\
\hline Passbook scheme & $3.57 \pm 1.12$ & $3.68 \pm 0.99$ & 0.204 \\
\hline Surgery hours & $3.85 \pm 0.92$ & $3.76 \pm 0.86$ & 0.002 \\
\hline Waiting time & $3.43 \pm 1.10$ & $3.40 \pm 0.93$ & 0.171 \\
\hline Condition of waiting room & $3.89 \pm 0.94$ & $3.29 \pm 0.96$ & $<0.001$ \\
\hline $\begin{array}{l}\text { Geographycal accessibility of the } \\
\text { surgery }\end{array}$ & $4.13 \pm 0.81$ & $3.75 \pm 0.75$ & $<0.001$ \\
\hline Available equipments & $4.02 \pm 0.81$ & $3.45 \pm 0.88$ & $<0.001$ \\
\hline Cleaniness of surgery & $4.25 \pm 0.77$ & $3.69 \pm 0.77$ & $<0.001$ \\
\hline
\end{tabular}

${ }^{1}$ Mann-Whitney test results

The ,general practitioner satisfaction index” was significantly higher among

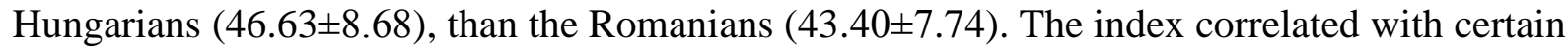
demographic characteristics, health status, and the frequency of using medical care (Table $15)$.

The opinions did not differ according to genders, however, age proved to be a determining factor in both groups. Younger people were less satisfied with their family doctor. The effect of the educational level only prevailed in the case of Hungarians. The most satisfied were those with higher educational qualifications. The existence of chronic illness had significant importance only among Hungarians. Those patients were more satisfied with their GP. Although the frequency of using family doctor care was significant in both groups, but the tendency was the opposite: The more frequently Hungarians turned to the GP the more satisfied they were, while regarding Romanians the most satisfied were those who did not see the doctor at all. 
Table 15 The ,general practitioner satisfaction index" and its correlation with demographic characteristics, health status, and the frequency of seeking family care

\begin{tabular}{|c|c|c|c|c|}
\hline \multirow[t]{2}{*}{ Characteristics } & \multicolumn{2}{|c|}{ Hungary } & \multicolumn{2}{|c|}{ Romania } \\
\hline & $\begin{array}{l}\text { average } \\
\pm \text { SD }\end{array}$ & P-value & $\begin{array}{l}\text { average } \\
\pm \text { SD }\end{array}$ & P-value \\
\hline Gender & & $0.345^{1}$ & & $0.510^{1}$ \\
\hline Female & $47.03 \pm 8.04$ & & $43.25 \pm 7.44$ & \\
\hline Male & $46.20 \pm 9.33$ & & $43.56 \pm 8.06$ & \\
\hline Age groups & & $0.001^{2}$ & & $<0.001^{2}$ \\
\hline $18-34$ years & $45.45 \pm 9.22$ & & $41.59 \pm 8.27$ & \\
\hline $35-54$ years & $46.03 \pm 9.28$ & & $43.74 \pm 8.13$ & \\
\hline older than 55 & $48.15 \pm 7.36$ & & $44.44 \pm 6.69$ & \\
\hline Level of education & & $0.002^{2}$ & & $0.278^{2}$ \\
\hline Primary education & $46.45 \pm 9.18$ & & $43.25 \pm 7.50$ & \\
\hline Secondary education & $47.35 \pm 8.31$ & & $43.14 \pm 7.84$ & \\
\hline Higher education & $44.96 \pm 8.59$ & & $44.34 \pm 8.14$ & \\
\hline Chronic disease & & $<0.001^{1}$ & & $0.225^{1}$ \\
\hline Yes & $47.62 \pm 8.36$ & & $43.71 \pm 7.42$ & \\
\hline None & $45.35 \pm 8.93$ & & $43.26 \pm 7.89$ & \\
\hline $\begin{array}{l}\text { Using family care in the } \\
\text { previous } 12 \text { months }\end{array}$ & & $<0.001^{2}$ & & $<0.001^{2}$ \\
\hline Not at all & $45.21 \pm 9.30$ & & $44.70 \pm 7.72$ & \\
\hline 1-2 times & $45.61 \pm 8.73$ & & $43.02 \pm 7.51$ & \\
\hline 3-6 times & $45.82 \pm 8.19$ & & $41.70 \pm 7.58$ & \\
\hline 7-12 times & $48.61 \pm 7.92$ & & $43.90 \pm 9.22$ & \\
\hline More than 12 times & $49.37 \pm 8.53$ & & $43.40 \pm 13.13$ & \\
\hline
\end{tabular}

${ }^{1}$ Mann-Whitney test results; ${ }^{2}$ Kruskal-Wallis test results 


\section{DISCUSSION}

The aim of this study was to characterize the health situation of Hungarian and Romanian citizens living on both sides of the border, and to define the target populations of interventions to promote health among people living on both sides of the Hungarian-Romanian border.

In respect of socio-economic status, health status and health behavior (harmful habits, using medical service) there were differences between the similar age and sex groups.

As for the subjective perception of educational level the Hungarians showed a more favourable picture, while regarding financial status the Romanians.

The self-assessment of health status is the best predictor of mortality. Therefore, subjective perception of health status is one of the most commonly used method for measuring the health in sociological studies. The subjective evaluation showed a favorable image among the Romanians. This data correlated to the occurrence of chronic diseases, known by the people in the survey. The Hungarians showed significantly higher rates in case of many chronic non-communicable diseases (allergy, gastrointestinal, musculoskeletal, cardiovascular diseases, etc.) as well.

Certain characteristics of health behavior showed a slightly different picture; behavioral factors that are harmful to health - smoking, unhealthy diet, physical inactivity was more frequent in the case of Romanians, while vegetable and fruit consumption was significantly more among Hungarians. Lifestyle factors showed a close relationship with age, sex, educational level, financial status, and certain behaviours with nutritional status too, both in Hungarian and Romanian groups. Our results suggest that the behavioral factors that affect health manifested in different ways in the two populations.

Several epidemiological studies have focused on geographic, social and economic factors, underlying the differences between health behaviours and health status. Besides the differences between countries, health inequalities within a country can also be observed in several European countries. The big difference in health conditions was the result of socioeconomic factors and the individual's health-destroying behaviour. ${ }^{65,66}$

Examining the cardiovascular disease risk factors in Ireland they found a relationship between socio-economic and lifestyle factors. ${ }^{67}$ German researchers examined the life expectancy, the economic and political factors and found that it is better in the economically more developed provinces. ${ }^{68}$ Lithuania explains the health inequalities with differences in the urbanization level, marital status, educational level, while Spanish and Dutch researchers in educational level, unemployment rate, smoking and alcoholism. ${ }^{69,70,71}$ 
A Dutch study showed a relationship between fruit and vegetable consumption and the occurrence of the most widespread diseases - cardiovascular disease and cancer. ${ }^{72}$ A Greek survey says that obesity, high blood pressure, high blood sugar and cholesterol level, physical activity and smoking are cumulative risk factors. ${ }^{23}$

In the 1960's in Hungary there were better health indicators than in Austria, but later a worsening was observed until the end of the 80s. It manifested particularly in negative mortality tendencies among middle-aged male population. In Europe middle-aged women's mortality rate was very unfavorable too.

Unusual, premature deaths cannot be explained with genetic reasons because in the '60s, the Hungarian mortality indicators were better than those of many developed Western countries. It cannot even be explained by impoverishment of the population either, because the most vigorous deterioration lasted until the middle of 1980 , and up to ' 89 the national gross domestic product increased significantly and until the end of ' 80 s the financial situation did not deteriorate even among the poorest people compared to the '60s. According to a number of results in health care statistics there was a significant improvement in the mortality rate regarding new-borns and elderly. Thus the deterioration of health, at least at a superficial level, cannot be explained with the worsening of medical care. ${ }^{73}$

Changes in the well-known self-harming behaviours which have national health importance like smoking, abnormal alcohol consumption, unhealthy diet are insufficient to understand this problem because they explain only about $40 \%$ of the relapse. On the other hand it is also a fundamental question what kind of psychological, motivational and social factors drive people into this more and more frequent self-harming behaviours. ${ }^{74}$

Even the most acknowledged international research teams' results show that in recent decades in the background of morbidity and mortality crisis in the changing Central and Eastern European countries there are crucial mental and behavioural aspects. The former explanatory hypotheses are not suitable to analyse these changes in mortality rate in such a short time. This is why the interest of the most excellent international research teams veered towards studying the so-called „Central-Eastern European health paradox”. 75

Exceptional socio-economic experiment is taking place in our region and by analysing it we can model how the socio-economic environment affects our health conditions through psychological and CNS processes. In the last decade, one of the most important public healthissues is that the primary health threats to civilized countries are low educational attainment. Educational level plays the most important role if we examine the mortality and morbidity data from the view of traditional risk factors such as smoking, obesity and sedentary lifestyle. 
In practice, this means that in England a person with basic education dies nearly 10 years earlier than a professional, even if he or she does not drink or smoke more. Michel Marmot and his colleagues carried out the most well-known studies. These studies have shown that the level of education has a very close inverse relationship with mortality rates among British public servants especially regarding the frequency of cardiovascular and chronic, not infectious respiratory disease. ${ }^{76}$ Between 1992-96 there was 10-year difference in life expectancy between the highest educated (graduates) and lowest skilled, unskilled British civil servants (78 and 68 years). The probability of heart attack caused death was 1.5 times higher amongst the poorly educated people even if they did not smoke or drink more. These differences were detectable within the countries and not between the countries. ${ }^{77}$

Mackenbach and his colleagues (2003) found that the quotient between mortality rate and the level of education is significantly higher among men in Hungary than in other European countries. In the case of men less than 74 years with lower educational level the mortality rate is 1.8 times higher than in the case of those with higher education level. Only in the Czech Republic have similar differences been detected, while among middle-aged women this difference in mortality rate is only 1.3 times higher.

A Swedish-Lithuanian (LiViCordia study) found that in 1970s the cardiovascular mortality rate among Lithuanian men was not worse than among Swedish men. Today, however, this rate is four times higher in Lithuania. It was found that the traditional risk factors for cardiovascular disease showed no worse characteristics in Vilnius (Lithuania), they do not smoke more heavily; what is more, the Swedish men's cholesterol levels were higher. However, significant differences were found in the psychological characteristics. The Lithuanian men were significantly more depressed and felt that in difficulties they could not count on the help of others. Also chronic stress and the so-called vital exhaustion were more typical among them. ${ }^{78}$

Studies $^{79}$ among Hungarian population show that low education is not in itself a factor that causes higher morbidity but rather the chronic stress and depressive symptoms lead to it. Consequently the main health- risk factor is not the lower education but the subjective feeling of being left behind. If someone is less educated, but not depressed, his or her health status is not worse as we can see it in the case of many wise old villagers. ${ }^{80}$

In our own study too we pointed out the differences between countries and within countries - influenced by socio-economic factors.

Our study demonstrated an association of smoking with socioeconomic status, such as low education and poorer financial conditions in Hungarians, and only with poor financial 
conditions in Romanians. Similar associations have been found by other studies, i.e. the risk of smoking is higher in low educated and poorer people. ${ }^{81,82,83}$ According to Wardle et al., cigarette smoking is more prevalent in lower social class respondents aged over 35 years. ${ }^{84}$ An investigation on 12 European countries (around 1990) has also revealed that smoking is more prevalent among the lower educated, particularly in Northern European countries. ${ }^{15}$ Socioeconomic inequalities in tobacco smoking are also revealed during the three periods of the Australian National Health Survey, e.g. males with the highest SES have been more likely to be never smokers than those with lower SES. ${ }^{19}$ In a Polish study, men with higher education (aged 18 to 66 years) are less likely to smoke compared to the less educated, whereas among women with higher education smoking is more common. ${ }^{16}$ Health interview surveys in Hungary also demonstrate that cigarette smoking is more prevalent among low educated and poorer people. ${ }^{85,86}$

The SES related variations in the prevalence of smoking could be influenced by the actual stage of smoking epidemic in a given country. ${ }^{15,87}$ Many countries in Eastern Europe such as Romania and Hungary are currently at stage 3 of the tobacco epidemic characterized by a marked downturn in smoking prevalence in men, a more gradual decline in women, especially in those with a higher educational level. ${ }^{15,21,87,88}$

In our study, the prevalence of unhealthy diet was higher in Romanians than in Hungarians. The low intake of fruits and vegetables was also found in Hungary by the „National Health Interview Survey". ${ }^{61}$ An overview of the health status of Romanians reports that low fruit and vegetable intake is one of the leading risk factors of non-communicable diseases. ${ }^{34}$ A study in Transylvania has found that vegetable intake is under reference values in females ${ }^{89}$, and another study delivered in 25-65-year old subjects has found higher prevalence of unhealthy diet in men. ${ }^{90}$

In agreement with other studies, we revealed an association of unhealthy diet with education and financial conditions in both countries. Wardle et al. have also found that low fruit and vegetable intake is more prevalent in lower social class respondents. ${ }^{84}$ Johansson et al. have reported that social status measured by education and aggregates of SES (blue-collar and white-collar workers and income per year) is correlated to indicators of healthy diet (e.g. fruit and vegetable consumption) in men and women aged 16-79 years, e.g. those having at least 13 years of education have higher intakes of fruits, vegetables and fibre than those with less than 13 years of education. ${ }^{25}$ Likewise, in a review paper about food patterns in terms of various socioeconomic indicators across Europe, it is stated that those who are poorer in material or social conditions are likely to follow a less healthy diet, i.e. people with lower 
SES consume nutrients from a less diverse food base: they eat monotonous diets with little variety. $^{24}$

In our study, leisure time physical inactivity of the participants was independent of their demographic and socioeconomic data in both countries - the result being in contrast with several reports in the literature. Haenle et al. have highlighted gender and age related differences in German adults aged 18-65 years; males are more likely than females to engage in more intense leisure time physical activity, and females in the youngest age group are the least physically active. ${ }^{91}$ A review of several studies describes that those with higher education levels or the self-employed are more likely to be moderately active in their leisure time. $^{24}$ The Hungarian national survey (2000) has described that higher educated and wealthier people are less likely to be physically inactive in their leisure time and/or at work ${ }^{64}$, while the next survey (2003) has found an association between financial conditions and inactivity only in females. ${ }^{86}$ An Australian survey points at strong socio-economic inequalities in terms of leisure time physical activity in both males and females ${ }^{19}$, however, no associations have been found between physical activity levels in leisure time and social status indices such as the level of education and annual income in the ATTICA study in Greece among 20-89 years old persons. ${ }^{23}$

A systematic review on the prevalence of obesity indicates geographic variations with rates being higher in Central, Eastern, and Southern Europe than in Western and Northern Europe. This geographic pattern can be explained, at least partly, by different socio-economic conditions as well as by lifestyle and nutritional factors, but may also be partly due to ethnic differences. ${ }^{92}$ The percentage of people who are overweight and obese reflects socioeconomic inequalities in Australia. ${ }^{19}$ In a study on males (53-75 years) in Denmark, leisure time physical activity is associated with obesity and social class. ${ }^{93}$ In our study, the prevalence of obesity was higher among Hungarians $(22,0 \%)$ than Romanians $(16,5 \%)$. The risk of obesity was higher in older people in both nations, and was associated with medium and low educational levels in Hungarians.

Obesity, associated with lifestyle and characterized by unbalanced diets high in calories and also by inadequate physical activity, is considered as a risk factor for numerous diseases. ${ }^{94}$ In our study, a positive association was found between leisure time physical inactivity and obesity in Hungarians, whereas a negative association was revealed in Romanians. The association between physical inactivity and obesity in Hungarians was in agreement with the results of FINRISK cross-sectional studies in the 25-64-years old population: leisure-time physical activity was inversely associated with obesity both in men 
and women. ${ }^{27}$ The negative association between leisure time physical inactivity and obesity in Romanians was inconsistent with most of the previous results. The findings of a prospective cohort study suggests, however, that high BMI is a determinant of sedentary lifestyle, but it has failed to provide unambiguous evidence for an effect of sedentary lifestyle on weight gain. ${ }^{95}$ This seemingly ambiguous result might be due to the fact that we examined only leisure time physical activity and did not cover activity during work. Those being engaged in strenuous physical activity during work are more probably inactive in their leisure time than those having a sedentary occupation. It should also be mentioned that the comparison of our physical activity related results with the findings of previous studies was slightly limited because the measurement for leisure time physical activity has not been previously validated.

In Romanians, unhealthy diet was associated with the risk of obesity, though no association was found in Hungarians. Our findings in Romanians are also in line with the results of FINRISK studies showing that obese subjects appear to consume less fruits and vegetables $^{27}$, and with the results of a cross-sectional study delivered in Romanian primary care settings in Iasi where obesity is more prevalent in case of unhealthy diet in males. ${ }^{90}$

No association was found between smoking and obesity in our study that is in contrast with several other reports. The study delivered in Iasi (Romania) has described higher rates of obesity among male smokers. ${ }^{90}$ The FINRISK study has highlighted that ex-smokers are heavier than non-smokers both among men and women. ${ }^{27}$ The Copenhagen male study reveals that leisure time physical activity and smoking habits are associated with obesity. ${ }^{93}$ The results of a cross-sectional study in 18-75 years show that smoking status, educational level, time spent in health related sport activities and sedentary behaviour are associated with the likelihood of being overweight. ${ }^{28}$

Taking the morbidity and mortality situation of the Hungarian population into consideration, a National Public Health Program was elaborated in 2003. The main methodology of the Program is primary prevention, but secondary and tertiary types are also included. The National Public Health Program aims to improve the health of the population. Its priority is the reduction of social inequalities, the primary prevention of non-infectious diseases, while preserving the epidemiological and environmental health and safety. ${ }^{45}$ In 2007 Romania adopted a National Public Health Program. Its priority was to improve the health status of the population and implementing measures and services to prevent and control diseases. The action plan includes the fight against infectious diseases, environmental protection, smoking, promotion of healthy lifestyles, etc. ${ }^{96}$ 
The priority in both countries is therefore the prevention of not contagious, chronic diseases, but the problem of infectious diseases must not be overlooked either. The most effective method to prevent them is the use of vaccination.

The epidemiological safety, prevention and control of communicable diseases are a priority task for the European Union countries. By consistent implementation of immunizations, vaccine-preventable diseases will not occour or maybe only sporadicly. ${ }^{97}$ The project that was launched in 2006 in Venice (Venice II from 2008) was designed to collect knowledge and best practice in field of vaccination among the joined 29 European countries and establish a knowledge base, which is capable of developing an efficient vaccination network, which can contribute to increase the epidemic safety. ${ }^{98}$

Recent measles outbreaks (involving Romania as well) drew attention again to the fact that insufficient vaccination coverage increases the risk of disease. Despite the fact that all the countries in the WHO European Region are committed to the elimination of measles, it was found that prior to the 2010 epidemic period $85 \%$ of patients did not receive the vaccination. To reach the goal - the elimination of measles by 2015 - over $95 \%$ coverage is required by using a two-dose regimen of measles-containing vaccines. ${ }^{99}$ Hungary's situation regarding elimination is very favourable: Since 2002, there have not been measles cases of indigenous origin. $^{100}$

This favorable situation is closely related to the fact that in our country ${ }^{101}$ the tuberculosis, diphtheria, tetanus, pertussis, poliomyelitis, Haemophilus influenzae type b meningitis, measles, mumps, rubella, and the hepatitis B vaccination coverage is high (99\%), although there are areas, where the rate of vaccination is slower, and there are children who cannot receive the required vaccination due to some illnesses. ${ }^{102}$ Family paediatricians, school doctors and nurses play dominant role in ensuring high vaccination coverage. It is not a negligible aspect either, that vaccinations are free and compulsory.

There were significant changes in the schedule and quality of immunization during the recent decades in Romania. Since 1990, some of the important goals of the Romanian Ministry of Public Health Disease Prevention department have been:

- enhancing the quality of the vaccination system,

- introducing heat-stable and combined vaccines,

- narrowing the vaccination contraindications,

- improving, monitoring and raising awareness of the importance of the cold chain as well as developing an appropriate information system. 
While until 1990, only vaccinations produced by the Bucharest Institute Cantacuzino were used, since 1990 other internationally approved vaccines as well have gradually been introduced in other countries using internationally approved vaccines. ${ }^{103}$ The age-related mandatory vaccination schedule has now evolved. This mass vaccination schedule in Romania also ensures the prevention of infectious diseases found in Hungarian vaccination schedule. Romanian immunization coverage regarding the compulsory vaccinations is quite good, though - according to the World Health Organization - in the last year (2011), a slight decline was observed. ${ }^{104}$

The recommended childhood vaccines show mostly similar trends in the two countries (Romania: hepatitis A, varicella, pneumococcal, meningococcal, rotavirus, Hungary: varicella, pneumococcal, meningococcal, hepatitis A, rotavirus, tick encephilitis) in both countries, seasonal influenza vaccination uptake is also recommended by the WHO guidelines. $^{105}$

Following vaccinations many previously disease-causing pathogens were suppressed and certain infectious diseases hardly occur. Today's parents have no personal experience of diphtheria or the severe course of the measles so some do not appreciate the importance of the vaccination, despite the fact that the bacteria are still present and they are part of our environment, or they can be introduced from other places again, so the risk of illness is still there. ${ }^{106}$ Despite the several advantages, it is undisputed that the vaccine can cause side effects or unpleasant complications. The vaccine-related fears and concerns are mainly grouped around four questions: can it cause autism, what are the risks of multiple vaccinations, whether the vaccines contain poison and whether naturally acquired immunity would be better. These dilemmas are subject to continuous objective analysis. ${ }^{107,108}$

Our results in both countries show that $3 / 4$ of the population find vaccinations important, slightly more in Romania. However, regarding knowledge of the recommended vaccines, there was a significant difference between the two countries. In Romania, the public is less familiar with these vaccines, than the Hungarian population. The majority of Romanians in the survey have not even heard about the recommended vaccinations and this was also reflected by their lack of knowledge regarding vaccine-preventable diseases. In Romania among vaccinations that can be taken voluntarily, they were only aware of the flu vaccine almost exclusively, while Hungarian people were familiar with almost all the available vaccinations. However, knowledge is not necessarily associated with demand. During our survey we found, that although Romanians had less knowledge of vaccinations, they would more likely to take non mandatory vaccinations compared to Hungarians. In both 
countries doctors have the greatest effect on the decision concerning the uptake of the recommended vaccination. Besides residence (country), opinions and attitudes towards vaccinations were significantly differentiated by gender and educational level. Women and those with higher education had wider knowledge about them and they found them more important. Also they demonstrated greater commitment to them.

The secondary prevention focuses on early detection of the disease (for example screening) and effective therapy. Our study showed significant difference between the two countries' participation in screening. Hungary showed higher participation rates except in the case of Chest x-ray (TB screening). This result may be related to the fact that in Romania soldiers, conscripted soldiers, pre-school children and their parents, marriageable couples, prisoners must be screened for TB. For teachers and people who work with food or in the food industry screening is compulsory every year. In Hungary - due to the domestic tuberculosis morbidity situation - the scope of people for whom TB screening is mandatory is continuously getting narrower.

Low turnout in breast and cervical screening partly can be explained by the fact that in Romania there is no organized breast screening, and cervical screening for women aged 25-64 was launched and extended to five years only in August 2012. ${ }^{109}$

People with lower income and educational level are overwhelmed with their own problems and therefore they are less likely to be concerned about possible future health problems. Consequently they are not aware of the importance of disease prevention. Experience has shown that invitations have a selective effect: they have less impact on the lower social groups than on the higher social groups. ${ }^{110}$

In addition to early diagnosis, effective treatment is also necessary, which can not be achieved without the patient's willingness to cooperate (compliance). To achieve this, patient satisfaction is particularly important because it has a significant influence on the patient's involvement in the whole healing process, thereby promoting its effectiveness ${ }^{59}$, ie. patient satisfaction is critical to the success of treatment.

Patient satisfaction is an important indicator of the quality of health care which depends on the doctor-patient, nurse -patient relationship, the organization of the institution, and the quality of information the patient receives.

In the last 30 years receiver attitudes have been replaced by customer behaviour, consequently, patient satisfaction has a growing role. ${ }^{111}$ The patients' satisfaction, and their preferences, as part of it, must be considered by every evidence-based health care and used 
while making decisions. It is an essential third factor besides scientific evidences and experiences. $^{125}$

According to our analysis of the role of home medical care did not differ between the two micro-regions along the border. In case of healt problems, as it corresponds to the function of primary care, the majority of respondents visit their GP first. However, there was difference in the frequency of using general medical care: Romanians turned less often to their GPs than the Hungarians. Overall satisfaction with the health care was practically the same in the two groups. However, Hungarians were more satisfied with medical care both on general level and the level of individual elements despite the fact that the two countries share many common features regarding primary care structure, such as free choice of physician, independent physician practice, the gatekeeper role of the GP. ${ }^{112,113}$ Certain aspects of satisfaction show that Hungarians were more satisfied with the material conditions, while the Romanians with the doctor-patient relationship. In the relation between ,general practitioner satisfaction index" and demographic characteristics, gender was regardless in both samples. However, age proved to be decisive (older people were more satisfied). The role of educational level was only detectable among Hungarians. In case of poor health status, having chronic disease(s) Hungarian patients were more satisfied, while among Romanians there was no difference. Although in different ways, but in both groups the number of people who availed themselves of family doctor care was determinative. The more frequently Hungarians turned to the GP the more satisfied they were, while regarding Romanians the most satisfied were those who did not see the doctor at all in the 12 months preceding the survey.

As for the use of health care, the different surveys - home survey (as part of European Health Interview Survey (EHIS) in autumn 2009, and „Global Health Survey" (GHS) with the participation of 28 countries) - showed a similar picture. According to the EHIS $76 \%$ of the Hungarian population visited their GP in the previous year. It is $78 \%$ for Hungarians and $73 \%$ for Romanians based on GHS data. According to our own data it was $83.3 \%$, vs. $66.8 \%$.

According to the literature it is very typical that more health counscious members of people in higher socio-economic position, who have higher educational level and lower risk to develop diseases in question, are more likely to seek and use these screening opportunities to maintain their health. The majority of respondents are satisfied with their family doctor, although our data show a slightly less favorable result compared to GHS ${ }^{114}$ results - own data for Hungary: 77.6\%, own data for Romania: 71.6\%; GHS-Hungary: 92\%, GHS-Roman: 87\%. A domestic survey among people living in a Hungarian village also reported similarly high 
satisfaction: $83.7 \%$ of the respondents were "satisfied" or "very satisfied" with the family doctor. $^{115}$

Tsovinar and his colleauges pointed out, however, that the high satisfaction does not always reflect the real situation: In Armenia, the majority of the population was satisfied despite the fact that there are substantial problems in general medical care, which was explained, that the doctor and the communication have a greater impact on satisfaction than the actual quality of care. ${ }^{116}$ Domestic and international researches have already investigated the influencing factors - age, education, health - of the patients' satisfaction with the general practitioner. Kertesz et al. found a similar association between satisfaction, age, and educational level. ${ }^{115}$ Barr et al. also found that the older and less educated people are more satisfied. ${ }^{117}$ Armenian researchers also found an inverse relationship between educational attainment and satisfaction of. ${ }^{116}$ Another study also demonstrated the same connection between educational attainment and satisfaction. ${ }^{118}$ Examining the satisfaction results, they found that education affects the patients' expectations and their satisfaction depends on the rate at which they are met. ${ }^{119}$

Similarly to our results other studies also found that health status is an important predictor of satisfaction. People with poorer health and those who need more frequent medical care have better opinion regarding family care. ${ }^{117,120}$

General practice is the most complete work process in patient care in accordance with the doctor's competences. Working as a general practicioner requires extremely complex, simultaneous, short- and long-term multi-level thinking and actions. The positive effects of proper quality assurance are high standard practices with all the required conditions. They contribute to achieving long-term health, which has positive effect on the expense of health insurance. $^{121}$

To isolate satisfaction as a specific dimension is important, because the vast majority of health care interventions and the associated communicative situations are unique and unrepeatable, therefore, a negative experience will be determinative even if the result would otherwise be appropriate or excellent. By monitoring the patients' opinions and feedback the quality of care will improve - in particular from the patients' perspective - and so they will be more satisfied. The satisfaction with health care is essentially determined by the difference in patients ' expectations and how they assess the care they received. In triggering positive judgments, psychosocial factors (communication, being well-informed, partnership, involvement in decisions) have primary roles, whose inadequacies do not automatically provoke discontent. The specific steps and conditions in patient care (different interventions, 
treatments, cleanliness etc) by themselves do not result in an appropriate level of satisfaction, however, even small imperfections and errors can cause dissatisfaction. ${ }^{122}$

The „Hungarian Health Care Standards” manual defines and contains the standards of home medical care and also the specific requirements of the profession that evaluates the quality of health services. The Manual's standards of quality management and evaluation (MIN.2) regulates the healthcare-related data collection, including patient satisfaction indicators too. The general requirements regarding indicators are: measuring, analysis and correction of identified discrepancies. ${ }^{56}$ The care quality indicators are able to analyze and evaluate the practice in its complexity. As an example, during the daily routine wide range of activities occur. Screening, treatment, care, informative sessions as well as therapeutic activities with the help of psychological management Also lifestyle advice is available within the very limited time. The primary expectation of the population is still short waiting time, quick diagnosis and suggestion of therapy, quick recovery or improvement in health without major changes in lifestyle and behaviour. Although there is a need for healthy lifestyle and physical fittness, but the efforts made are not enough yet. The ,satisfaction questionnaire” we used in the study was suitable for surveying patients' opinion regarding family care.

With the method we used we were able to uncover similar results to those revealed by domestic and international researches. Based on this, we believe that it could be used routinely in a broader survey, to measure care satisfaction. In the future, following the changes we could assess the impact and effectiveness of the introduced measures. 


\section{CONCLUSION}

From the respect of health policy decisions are crucial to explore the health situation of a given area. Our survey examined the demographic and social situation, health status, health behavior and using health care among people living along the Hungarian-Romanian border. As for the latter factors like using health care, attitudes towards screenings and immunizations and their influencing socio-demographic factors (ethnicity, age, educational level, etc.) were highlighted, because examining the population's health, health using habits and satisfaction with health care may contribute to decide what kind of development and structural changes are needed.

It is known that the morbidity and mortality attributed to chronic diseases are the major public health problems both in Hungary and Romania. The improvement of healthpromoting behaviour is a basic problem in the prevention of chronic diseases. A healthy lifestyle, with its behavioural emphasis might not depend only on the individuals' decisions. Individuals can make choices in a social context, and helping individuals to change unhealthy behaviour should always be part of the health promotion. Our study may call the attention to the inequalities in smoking and dietary habits in relation to the socioeconomic status: the occurrence of health-damaging behaviours was more common among the less educated people in both countries. According to our results planning interventions, special attention should be paid to the geographically, infrastucturally, socially and demographically disadvantaged population groups to provide equal opportunities for them to conduct/live a healthy way of life.

Although the acceptance of important vaccines for primary prevention among the citizens of both countries can be considered general, some degrees of inequality can be observed and they must be kept in mind. Physicians and nurses should pay more attention to inform both men and the less educated about not just mandatory, but recommended vaccinations as well, thereby encouraging the population to take the vaccines not just because they are mandatory but because they have adequate information and knowledge about them and they subsequently desire to take them.

Organized public health screening tests have become important areas for improvement. From our records it appears that especially the Romanian side needs improvements in this area, but also the Hungarian conditions are far from the desired level.

The fact that the emerging health and health-related problems on both sides of the border and their socioeconomic background have common characteristics may draw our 
attention to the importance of seeking for mutual solutions. These might be realised in the framework of cross-border community based health promotion programmes that would be supported by the European Union, thus, the common problems occurring in the regions near the border could be solved together. Our study may provide some practical implications for formulating programmes that are aimed at improving the healthy behaviour in Hungarians and Romanians, especially in the Danube-Kris-Mures-Tisa Euroregion. Our results may point out the need for developing interventional strategies, focusing more on people in lower socioeconomic status, in order to reduce the existing inequalities in health and health-related behaviours. 


\section{REFERENCES}

${ }^{1}$ World Health Organization. Preventing Chronic Diseases: A Vital Investment. Geneva; 2005. http://www.who.int/chp/chronic_disease_report/full_report.pdf [accessed 19 December 2010]

${ }^{2}$ World Health Organization Regional Office for Europe. Gaining Health. The European Strategy for the Prevention and Control of Noncommunicable Diseases. 2006. http://www.euro.who.int/document/E89306.pdf [accessed 19 December 2010]

${ }^{3}$ Központi Statisztikai Hivatal - Eurostat statikus táblák http://www.ksh.hu/docs/hun/eurostat_tablak/tabl/tps00025.html [accessed 10 November 2008]

${ }^{4}$ Központi Statisztikai Hivatal - Tájékoztatási adatbázis http://www.ksh.hu [accessed 10 November 2008]

${ }^{5}$ Institutul National De Statistica http://www.insse.ro [accessed 10 November 2008]

${ }^{6}$ Ádány R.: A magyar lakosság egészségi állapota az ezredfordulón. Medicina, Budapest, 2003.

${ }^{7}$ Marmot, M. G., Kogevinas, M., Elston, M. A.: Social/economic status and disease. Public Health, 1987; 8, 111-135.

${ }^{8}$ Colditz G.: Economic costs of obesity and inactivity. Medicine and Science in Sport and Exercise, 1999; 31, 663-667.

${ }^{9}$ Banwell, C., Hinde, S., Dixon, J.: Obesity Reflections on expert consensus: a case study of the social trends contributing to obesity. Eur J Public Health, 2005; 15, 6, 564-568.

${ }^{10}$ Vitrai J., Vokó Z.: Egy korszerü szemléleten alapuló egészségmodell. Családorvosi Fórum, 2002; 10, 39-41.

${ }^{11}$ Bruin, A., Nossikov, A.: Health interview surveys towards international harmonization of methods and instruments. World Health Organization Regional Office for Europe, Copenhagen. 1996.

${ }^{12}$ Stronks, K., Looman C. W.: The importance of psychosocial stressirs for socioeconomic inequalities in perceived health. Soc Sci Med, 1998; 46, 611-623.

${ }^{13}$ Mackenbach, J. P.: Widening socioeconomic inequalities in mortality in six Western European countries. International Journal of Epidemiology, 2003; 32, 830-837.

14 Európai Lakossági Egészségfelmérés

(2009).

http://portal.ksh.hu/pls/ksh/docs/hun/elef/index.html [accessed 17 April 2010] 
${ }^{15}$ Cavelaars A.E.J.M., Kunst A.E., Geurts J.J.M., Crialesi R., Grötvedt R.C.L., Helmert U., Lahelma E., Lundberg O., Matheson J., Mielck A.: Educational differences in smoking: international comparison. BMJ, 2000; 320(22):1102-1107.

${ }^{16}$ Woitas-Slubowska D., Hurnik E., Skarpanska-Stejnborn A.: Correlates of smoking with socioeconomic status, leisure time physical activity and alcohol consumption among Polish adults from randomly selected regions. Centr Eur J Public Health, 2010; 18(4):179-185.

${ }^{17}$ Halling A., Unell L.: General health and tobacco habits among middle-aged Swedes. Eur J Public Health, 2006; 17(2):151-154.

${ }^{18}$ Molarius A., Berglund K., Eriksson C., Lambe M., Nordström E., Eriksson H.G., Feldman I.: Socioeconomic conditions, lifestyle factors, and self-rated health among men and women in Sweden. Eur J Public Health, 2006; 17(2):125-133.

${ }^{19}$ Najman J.M., Toloo G., Siskind V.: Socioeconomic disadvantage and changes in health risk behaviours in Australia: 1989-90 to 2001. Bulletin of the World Health Organization, 2006; 84:976-984.

${ }^{20}$ Fong C.W., Bhalla V., Heng D., Chua A.V., Chan M.L., Chew S.K.: Educational inequalities associated with health-related behaviours in the adult population of Singapore. Singapore Med J, 2007; 48:1091-1099.

${ }^{21}$ Edwards R: The problem of tobacco smoking. BMJ, 2004; 328(24):217-219.

${ }^{22}$ European Opinion Research Group EEIG: Special Eurobarometer 183-6/Wave 58.2. Physical activity. http://ec.europa.eu/public_opinion/archives/ebs/ebs_183_6_en.pdf European Commission 2003. [accessed 10 November 2008]

${ }^{23}$ Pitsavos C., Panagiotakos D.B., Lentsas Y., Stefanadis C.: Epidemiology of leisure-time physical activity in socio-demographic, lifestyle and psychological characteristics of men and women in Greece: the ATTICA Study. http://www.biomedcentral.com/1471-2458/5/37 [accessed 10 November 2008] BMC Public Health, 2005; 5:37. doi:10.1186/1471-2458-5-37 ${ }^{24}$ Dowler E: Inequalities in diet and physical activity in Europe. Public Health Nutrition, 2001; 4(2B):701-709. doi: 10.1079/PHN2001160

${ }^{25}$ Johansson L., Thelle D.S., Solvoll K., Bjorneboe G-E.A., Drevon C.A.: Healthy dietary habits in relation to social determinants and lifestyle factors. Br J Nutr, 1999; 81:211-220.

${ }^{26}$ Sundquist J., Johansson S-E.: The influence of socioeconomic status, ethnicity and lifestyle on body mass index in a longitudinal study. Int J Epidemiol, 1998; 27:57-63. 
${ }^{27}$ Lahti-Koski M., Pietinen P., Heliövaara M., Vartiainen E.: Associations of body mass index and obesity with physical activity, food choices, alcohol intake, and smoking in the 19821997 FINRISK Studies. Am J Clin Nutr, 2002; 75:809-817.

${ }^{28}$ Duvigneaud N., Wijndaele K., Matton L., Deriemaeker P., Philippaerts R., Lefevre J., Thomis M., Duquet W.: Socio-economic and lifestyle factors associated with overweight in Flemish adult men and women. http://www.biomedcentral.com/1471-2458/7/23 [accessed 10 November 2008] BMC Public Health, 2007; 7:23. doi:10.1186/1471-2458-7-23

${ }^{29}$ Olsen K.M., Dahl S-A.: Health differences between European countries. Soc Sci Med, 2007; 64:1665-1678.

${ }^{30}$ Zatonski W.: The East-West Health Gap in Europe - what are the causes? Eur J Public Health, 2007; 17:121.

${ }^{31}$ McKee M., Balabanova D., Steriu A.: A new year, a new era. Romania and Bulgaria join the European Union. Eur J Public Health, 2007; 17:119-20.

${ }^{32}$ KSH Demográfiai Évkönyv 2009. Budapest, 2010.

${ }^{33}$ Dumitrache L., Armas I.: The health state of the Romanian population during the transition period. GeoJournal, 1998; 44(2):151-160.

34 WHO Regional Office for Europe: Highlights on health in Romania 2005. http://www.euro.who.int/document/e88529.pdf World Health Organization; 2006. [accessed 19 December 2010]

35 WHO Regional Office for Europe: European Health for All Database. http://data.euro.who.int/hfadb/ [accessed 19 December 2010]

${ }^{36}$ Dolea C., Nolte E., McKee M.: Changing life expectancy in Romania after the transition. J Epidemiol Community Health, 2002; 56:444-449.

37 Uzzoli A., Szilágyi D.: Life expectancy and its regional inequalities in Hungary. Geographica Pannonica, 2009; 13(4):127-136.

38 Jurányi R.: A fertőző betegségek általános és részletes járványtana. Medicina Kiadó, 1998.

39 A védőoltások története: az empirikus felhasználástól a tervezett kutatások alapján fejlesztett oltóanyagokig.

http://www.informed.hu/index.nfo?tPath=/betegsegek/gyacs/application/\&article_id=70803. [accessed 15 March 2012]

${ }^{40}$ A kiterjesztett immunizációs program.

http://www.informed.hu/?tPath=/print/betegsegek/gyacs/application\&article_print=yes\&articl e_id=70799. [accessed 2 April 2012] 
${ }^{41}$ Global Trends in Immunization.

http://www.globalhealthmagazine.com/cover_stories/vaccines_a_top_priority/ [accessed 23 April 2012]

${ }^{42}$ Melles M.: A vakcinológia régen és most. 17. Országos Védőoltási Továbbképző Tanfolyam. Tapolca, 2011.

${ }^{43}$ Smith J. et al: Certification of polio eradication: process and lessons learned. Bull. World Health Organ. Geneva, 2004;82(1) http://www.scielosp.org/scielo.php?pid=S004296862004000100007\&script=sci_arttext [accessed 20 April 2012]

44 Harmat Gy., Czárán E.: Szürési gyakorlat Európában; Egészségügyi Gazdasági Szemle, 2010; 2, 2-11.

${ }^{45}$ Egészség Évtizedének Népegészségügyi Programjáról szóló módosított 46/2003 (IV.16.) OGY határozat

46 OLEF (2000): Gyorsjelentés az országos lakossági egészségfelmérésről. http://www.gallup.hu/olef/gyors.html [accessed 12 March 2009]

${ }^{47}$ Pető É., Müller A., Paulik E., Pikó B.: A betegelégedettségi vizsgálat helye és szerepe az egészségügyi kimenet mérésében. Egészségügyi Gazdasági Szemle, 1995; 33; 487-499.

${ }^{48}$ Gulácsi L. (szerk.): Minőségfejlesztés az egészségügyben. Medicina Könyvkiadó Rt, Budapest, 2000.

${ }^{49}$ Cleary P.D., McNeil B.J.: Patient satisfaction aa an indicator of quality care. Inquiry 1988;25:25-36.

${ }^{50}$ Zastowny R.T., Roghmann K.J., Cafferata G.L.: Patientsatisfaction and the use of health services: explorations in causality. Medical Care 1989; 27: 705-721.

${ }^{51}$ Thompson A.: Customizing the public for health care: What's in a label? In: The politics of quality int he public sector: the management of changr.(szerk.:Kirkpatrick I., Martinez-Lucio M.) Routledge, London, 1995.

${ }^{52}$ Sackett D.L., Straus S.E., Richardson W.S. et al.: Evidence-Based Medicine. How to Practice and Teach EBM. New York: Churchill Livingstone, 1997.

${ }^{53}$ Belicza É., Boján F.: A hazai kórházak minőségfejlesztési tevékenysége, áttekintő értékelés kérdőíves elemzés alapján. 1994, EMIKK 1, Debrecen, 5.

54 Ovretveit, J.: Minőségszemlélet az egészségügyben: Bevezetés az egészségügyi szolgáltatások minőségügyi módszertanába. Medicina, Budapest, 1999.

${ }^{55}$ Gődény S.: A klinikai hatékonyság fejlesztése az egészségügyben. Pro die, Budapest, 2007. 
${ }^{56}$ Magyar Egészségügyi Ellátási Standardok kézikönyv (MEES) 1.0 változat, Egészségügyi Minisztérium, 2007.

${ }^{57}$ Második Országos Betegelégedettségi Vizsgálat. I-II. kötet. Társadalomkutatási Intézet Rt. Budapest, 2001.

${ }^{58}$ Pető É., Heathcote G., Paulik E., Müller A.: Betegellátás és minőség I. (magyar és angol betegek véleménye alapján). A hospitalizáció körülményei. Egészségügyi Gazdasági Szemle, 1994; 32 (2):225-236.

${ }^{59}$ Hirdi H.: Betegelégedettség mérése a családorvosi gyakorlatban. Ápolásügy, 2004; 3, www.apolasiegyesulet.hu Letöltve: 2010. február 12. [accessed 12 February 2010]

${ }^{60}$ The Gallup Organization, Flash Eurobarometer 253: Survey on Tobacco. Analytical report. http://ec.europa.eu/public_opinion/flash/fl_253_en.pdf 2009. [accessed 19 December 2008]

${ }^{61}$ Széles Gy: Táplálkozás. (Nutrition.).

http://www.egeszsegmonitor.hu/dok/kutatasi_jelentes_OLEF2000.pdf [accessed 19 December 2008] In Országos Lakossági Egészségfelmérés OLEF 2000. (National Health Interview Survey.) Edited by Boros J, Németh R, Vitrai J. Országos Epidemiológiai Központ, Budapest; 2002, 3-65-3-75.

${ }^{62}$ Fifty-seventh World Health Assembly: Global strategy on diet, physical activity and health. http://apps.who.int/gb/ebwha/pdf_files/WHA57/A57_R17-en.pdf [accessed 10 November 2008]

${ }^{63}$ Cavil N., Kahlmeier S., Racioppi F. (Eds): Physical activity and health in Europe: evidence for action World Health Organization; 2006.

${ }^{64}$ Széles Gy: Testmozgás. (Physical activity.).

http://www.egeszsegmonitor.hu/dok/kutatasi_jelentes_OLEF2000.pdf [accessed 19 December 2008] In Országos Lakossági Egészségfelmérés OLEF 2000. (National Health Interview Survey.) Edited by Boros J, Németh R, Vitrai J. Országos Epidemiológiai Központ, Budapest; 2002, 3-55-3-64.

${ }^{65}$ Uzzoli A.: Az egészségi állapot társadalmi-területi különbségei Magyarországon. 2005. http://geogr.elte.hu/REF/REF_Tezisek/UA_tezisek.pdf [accessed 19 December 2008]

${ }^{66}$ Józan P.: A századvég halálozási viszonyainak néhány jellegzetessége Magyarországon. Századvég, 2000; Tavasz 16, 29-44.

${ }^{67}$ Creagh, D., Neilson, S.: Established cardiovascular disease and CVD risk factors in a primary care population of middle-aged Irish men and women. 2002. http://www.ncbi.nlm.nih.gov/pubmed/12542011 [accessed 17 November 2008] 
${ }^{68}$ Helmert, U., Streich, W., Borgers, D.: Regional differences in trends in life expectancy and the influence of the political and socioeconomic contexts in Germany. International Journal of Health Services, 2003; 33, 4, 669-686.

${ }^{69}$ Kalediene, R., Petrauskiene, J.: Regional life expectancy patterns in Lithuania. European Journal of Public Health, 2000; 10, 2, 101-104.

${ }^{70}$ Gutierrez-Fisac, J. L., Gispert, R., Sola, J.: Factors explaining the geographical differences in Disability Free Life Expectancy in Spain. Journal of Epidemiology \& Community Health, 2000; 54, 6, 451-455.

${ }^{71}$ Groenewegen, P. P., Westert, G. P., Boshuizen, H. C.: Regional differences in healthy life expectancy in the Netherlands. Public Health, 2003; 117. 424-429.

${ }^{72}$ Veerman, J. L., Barendregt, J. J., Mackenbach, J. P.: The European Common Agricultural Policy onfruits and vegetables: exploring potential health gain from reform. European Journal of Public Health, 2006; 16, 1, 31-35.

${ }^{73}$ Andorka R.: Társadalmi változások Magyarországon az utolsó években. Magyarország Politikai Évkönyve. 1992.

${ }^{74}$ Kopp M.: Psychosocial risk factors, inequality and self-rated morbidity in a changing society. Social Sciences and Medicine, 2000; 51, 1350-1361.

${ }^{75}$ Cornia G. A., Panicia R.: The Mortality Crisis in Transitional Economies. Oxford University Press, 2000; Oxford, 104.

${ }^{76}$ Marmot M. G.: Health inequalities among British servants: the Whitehall II study. Lancet, 1991; 337, 1387-1393.

${ }^{77}$ Marmot, M. G.: The status syndrome: How social standing affects our health and longevity. Times Books, 2004; New York.

${ }^{78}$ Kristenson, M., Kucinskiene, Z.: Possible causes of the differences in coronary heart disease mortality between Lithuania and Sweden: the Li-Vi-Cordia study. Public Health, 2002; 29, 140-150.

${ }^{79}$ Kopp M., Skrabski Á.: A Magyar népesség életkilátásai. Magyar Tudomány, 2007; 9, 1149.

${ }^{80}$ Skrabski Á.: A 45-64 éves népesség egészségi állapota - a közép-kelet európai egészség paradoxon.

http://www.doki.net/tarsasag/mok/upload/mok/document/45_64_nepesseg_egeszsegi_allapota .pdf 2005. [accessed 17 April 2010]

${ }^{81}$ Laaksonen M., Rahkonen O., Karvonen S., Lahelma E.: Socioeconomic status and smoking - Analyzing inequalities with multiple indicators. Eur J Public Health, 2005; 15:262-269. 
${ }^{82}$ Barbeau E.M., Leavy-Sperounis A., Balbach E.D.: Smoking, social class, and gender: what can public health learn from the tobacco industry about disparities in smoking? Tob Control 2004, 13:115-120.

${ }^{83}$ Giskes K., Kunst A.E., Benach J., Borrell C., Costa G., Dahl E., Dalstra J.A., Federico B., Helmert U., Judge K., Lahelma E., Moussa K., Ostergren P.O., Platt S., Prattala R., Rasmussen N.K., Mackenbach J.P.: Trends in smoking behaviour between 1985 and 2000 in nine European countries by education. J Epidemiol Community Health, 2005; 59:395-401. doi: 10.1136/jech.2004.025684

${ }^{84}$ Wardle J., Steptoe A.: Socioeconomic differences in attitudes and beliefs about healthy lifestyles. J Epidemiol Community Health, 2003; 57:440-443.

${ }^{85}$ Boros J.: Dohányzás. (Smoking.).

http://www.egeszsegmonitor.hu/dok/kutatasi_jelentes_OLEF2000.pdf [accessed 19 December 2008] In Országos Lakossági Egészségfelmérés OLEF2000. (National Health Interview Survey.) Edited by Boros J, Németh R, Vitrai J. Országos Epidemiológiai Központ, Budapest; 2002, 3-40-3-54.

${ }^{86}$ Boros J.: Egészségmagatartás. (Health behaviour.). http:/ / www.nyme.hu/ fileadmin/ dokumentumok/ atfk/ tematikak/ TESTNEVELES_TANSZEK/ dr_ihasz_ferenc_csatolhato_dok/ 2_fejezet_egeszsegmagatartas_olef_2 003.pdf [accessed 19 December 2008] Országos Lakossági Egészségfelmérés OLEF 2003. (National Health Interview Survey.) Országos Epidemiológiai Központ; 2005.

${ }^{87}$ Lopez A.D., Collishaw N.E., Piha T.: A descriptive model of the cigarette epidemic on developed countries. Tob Control, 1994; 3:242-247.

${ }^{88}$ Shafey O., Dolwick S., Guindon G.E. (Eds): Tobacco Control Country Profiles 2003. American Cancer Society, Atlanta, GA; 2003.

${ }^{89}$ Zapirtan H., Ionut C., Vlad M., Creteanu E., Sinca A.: Dietary imbalance in some communities of Transylvania. Rev Med Chir Soc Med Nat Iasi, 2006; 110(4):993-998.

${ }^{90}$ Bunescu D.M., Stoffers H.E., van den Akker M., Jan G.: Coronary heart disease and cardiovascular risk factors among people aged 25-65 years, as seen in Romanian primary healthcare. Eur J Gen Pract, 2008; 14(2):56-64.

${ }^{91}$ Haenle M.M., Brockmann S.O., Kron M., Bertling U., Mason R.A., Steinbach G., Boehm B.O., Koenig W., Kern P., Piechotowski I., Kratzer W., the EMIL-Study group: Overweight, physical activity, tobacco and alcohol consumption in a cross-sectional random sample of 
German adults. http://www.biomedcentral.com/1471-2458/6/233 [accessed 10 November 2008] BMC Public Health, 2006; 6:233. doi:10.1186/1471-2459-6-233

${ }^{92}$ Berghöfer A., Reinhold T., Apovian C.M., Sharma A.M., Willich S.N.: Obesity prevalence from a European perspective: a systematic review. http://www.biomedcentral.com/14712458/8/200 [accessed 10 November 2008] BMC Public Health, 2008; 8:200. doi:10.1186/1471-2458-8-200

${ }^{93}$ Suadicani P., OleHein H., Gyntelberg F.: Lifestyle, social class, and obesity - the Copenhagen Male Study. Eur J Cardiovasc Prev Rehabil, 2005; 12:236-242.

94 Haffner S., Taegtmeyer H.: Epidemic obesity and the metabolic syndrome. http://circ.ahajournals.org/content/108/13/1541 [accessed 17 November 2010] Circulation, 2003; 108:1541-1545. 2003. doi: 10.1161/01.CIR.0000088845.17586.EC

${ }^{95}$ Mortensen L.H., Siegler I.C., Barefoot J.C., Gronbaek M., Sorensen T.I.A.: Prospective associations between sedentary lifestyle and BMI in midlife. Obesity, 2006; 14:1462-1471.

${ }^{96}$ Ministerul Sanatatii Programe nationale - 2007 http://www.ms.gov.ro/?pag=133 [accessed 15 March 2012]

${ }^{97}$ Védőoltások Napja. Epinfo, 2004;11(23):2-3.

98 Vaccine European New Integrated Collaboration Effort. http://venice.cineca.org/the_project.html [accessed 15 March 2012]

99 A kanyaró járványügyi helyzete az EU/EGK országokban, 2011. május 12. Epinfo, 2011;18(19):197-202.

${ }^{100}$ Kanyarójárvány Ukrajnában, a betegség potenciális terjedése az Európai Unió területén és Magyarországon. Epinfo, 2012;19(15): 161-169.

101 Az Országos Epidemiológiai Központ Módszertani Levele 2012. évi védőoltásokról. Epinfo 2012;19:1. Különszám

102 Magyarország 2009. évi járványügyi helyzete. Epinfo 2011;18:7. Különszám

${ }^{103}$ Alkalmazott védőoltások és oltási rend Romániában. Epinfo 2001;8(17):2-5.

104 WHO Vaccine-Preventable Diseases: Monitoring System 2012 Global Summary. http://apps.who.int/immunization_monitoring/en/globalsummary/countryprofileresult.cfm [accessed 2 August 2012]

105 Schema de vaccinare valabila in 2011. Vaccinarile optionale. http://www.copilul.ro/sugar/vaccin-copii/Schema-de-vaccinare-valabila-in-2011-a8803.html [accessed 2 August 2012]

${ }^{106}$ Straub I.: Korunk fertőző betegségei. SubRosa Kiadó, 1995. 
${ }^{107}$ Miller N.Z.: Védőoltások - kérdések és kételyek. Kétezeregy Kiadó, 2003. 108 Tények tés é a védőoltásokról. http://medizona.hu/test_es_lelek/20081110_oltas_tenyek_tevhitek.aspx [accessed 3 May 2012]

${ }^{109}$ Fancsali A.: A korai felismerés életet menthet; http://szekelyhon.ro/aktualis/marosszek/akorai-felismeres-eletet-menthet [accessed 3 May 2012]

${ }^{110}$ Döbrőssy L., Kovács A., Döbrőssy B., Budai A., Boncz I., Margitai B., Koós T.: Miért kihasználatlan hazánkban a szervezett lakosságszürés? LAM, 2010;20(10):689-693.

111 Thompson A. (1996): Customizing the public for health care: What's in a label? Routledge, London.

${ }^{112}$ Health Care Systems in Transition. Romania 2000. European Observatory on Health Care Systems, 2000.

${ }^{113}$ Vladescu C., Scintee G., Olsavszky V., Allin S., Mladovsky P.: Romania: Health system review. Health Systems in Transition, 2008; 10(3):1-172.

${ }^{114}$ International Research Institute: Global Health Survey, 2011. Experience \& Perception in 28 Countries. http://dynamic-search.com.my/wp-content/uploads/2012/02/IRIS-GlobalHealth-Survey-Final.pdf [accessed 5 May 2012]

115 Kertész A., Balogh S., Nagymajtényi L., Paulik E.: A háziorvosi ellátással való elégedettség demográfiai sajátosságai. Medicus Universalis, 2006; 39 (4): 117-121

116 Tsovinar H., Demirchyan A., Thompson M. E., Petrosyan V.: Patient satisfaction with primary care in Armenia: good rating of bad services? Health Services Management Research, 2010; 23: 12-17. DOI: 10.1258/hsmr.2009.009012

${ }^{117}$ Barr D. A., Vergun P., Barley S. R.: Problems in using patient satisfaction data to assess the quality of care provided by primary care physicians. Journal of Clinical Outcomes Managament, 2000; 7(9): 19-24

118 Hall J. A., Dornan M. C.: Patient sociodemographic characteristics as predictors of satisfaction with medical care: a meta-analysis. Social Science and Medicine, 1990; 30: 811818

${ }^{119}$ Bleich S. N., Özaltin E., Murray C. J. L.: How does satisfaction with health-care system relate to patient experience? Bulletin of World Health Organization, 2009; 87: 271-278. DOI: 10.2471/BLT.07.050401 
${ }^{120}$ Klemenc-Ketis Z., Petek D., Kersnik J.: Association between family doctors practices characteristics and patient evaluation of care. Health Policy, 12 May 2012 (Epub ahead of print)

121 Selmeczi K.: Minőségbiztosítás a létéért küzdő alapellátásban. http://www.fakoosz.hu/index.php?pg=sub_339 [accessed 17 April 2010]

${ }^{122}$ Hunya É.: Ugye, ízlett az ebéd? Egészségügyi Menedzsment, 2000; 1:51-53.

${ }^{123}$ Dalstra J.A.A., Kunst A.E., Borrell C., Breeze E., Cambois E., Costa G., Geurts J.J.M., Lahelma E., Oyen H. Van, Rasmussen N.K., Regidor E., Spadea T., Mackenbach J.P.: Socioeconomic differences in the prevalence of common chronic diseases: an overview of eight European countries. Int J Epidemiol, 2005; 34:316-326.

124 WHO Technical Report Series 894: Obesity: preventing and managing the global epidemic. Part 1. http://whqlibdoc.who.int/trs/WHO_TRS_894_(part1).pdf [accessed 10 November 2008] World Health Organization, Geneva, 2000

125 Haynes R., Sackett D.L.: Transferring evidence from research into practice. EvidenceBased Medicine, 1997; 3-6. 